\section{Nutrient accumulation and export in teak (Tectona grandis L.f.) plantations of Central America}

\author{
Jesus Fernández-Moya ${ }^{(1-2)}$, Rafael Murillo ${ }^{(2-3)}$, Edward Portuguez ${ }^{(2-4)}$, \\ Juan Luis Fallas ${ }^{(2-5)}$, Vinicio Ríos ${ }^{(2-6)}$, Folkert Kottman ${ }^{(2-6)}$, Jean Marc \\ Verjans ${ }^{(2-7)}$, Rafael Mata ${ }^{(2)}$, Alfredo Alvarado ${ }^{(2)}$
}

This study aims at assessing the nutrient sustainability of highly productive teak plantations in Central America by analyzing the nutrient accumulation dynamics at different ages and the allocation patterns throughout a rotation period. Three teak plantations (28 stands of different ages) were selected in Costa Rica and Panama, and nutrient and biomass accumulation and allocation in different tree components (bole, bark, branches and foliage) were measured in the best performing trees between 1 and 19 years of age. A stand of 150 teak trees ha ${ }^{-1}$ at age 19 would accumulate $\left(\mathrm{kg} \mathrm{ha}^{-1}\right) 405 \mathrm{~N}, 661 \mathrm{Ca}, 182 \mathrm{~K}, 111$ $\mathrm{Mg}, 33 \mathrm{P}, 53 \mathrm{~S}, 9 \mathrm{Fe}, 0.47 \mathrm{Mn}, 0.22 \mathrm{Cu}, 0.92 \mathrm{Zn}, 1 \mathrm{~B}$; whereas the expected nutrient export by timber harvest (bole and bark) is ( $\left.\mathrm{kg} \mathrm{ha}^{-1}\right) 220 \mathrm{~N}, 281 \mathrm{Ca}, 88$ $\mathrm{K}, 63 \mathrm{Mg}, 23 \mathrm{P}, 39 \mathrm{~S}, 6 \mathrm{Fe}, 0.13 \mathrm{Mn}, 0.10 \mathrm{Cu}, 0.21 \mathrm{Zn}, 0.40 \mathrm{~B}$. Our results sug gest that teak nutrition should pay special attention to $\mathrm{N}$ and $\mathrm{K}$, the nutrients most accumulated by teak along with $\mathrm{Ca}$. In addition, $\mathrm{P}$ and $\mathrm{B}$ could also be limiting the productivity of planted teak stands due to their general soil deficiencies. Proposed models estimate the amount of nutrients removed from the site during timber harvests, information that can be used by plantation managers to avoid soil nutrient depletion, approaching sustainability in forest plantation management.

Keywords: Forest Nutrition, Planted Forests, Costa Rica, Panama, Sustainability, Forest Soils

\section{Introduction}

Due to growing needs for timber and wood products, forest plantations have increased around the world and have gained economical relevance. At the same time there has been an increase in concerns regarding the sustainability of planted forests, especially those managed under a regime of short rotations (Nambiar 1995). In particular, the relationship between forest nutrition and sustainable timber production has become an important issue for the management of less stu- died species in countries such as Costa Rica and China (Ma et al. 2007, Arias et al. 2011, Qiong et al. 2011)

Teak (Tectona grandis L.f.) plantations have been widely established in Central America, initially in Costa Rica and Panama (De Camino et al. 2002) and more recently in Guatemala, El Salvador and Nicaragua. Teak has become an important species in the worldwide quality tropical hardwood sector (Pandey \& Brown 2000), with a total planted area of $4.3 \cdot 10^{6}$ ha (not including natural ar-
(1) Dept. Silvopascicultura, E.T.S.I Montes, Universidad Politécnica de Madrid (UPM), Ciudad Universitaria s/n, E-28040 Madrid (Spain); (2) Centro de Investigaciones Agronómicas, Universidad de Costa Rica (CIA-UCR), San Pedro (Costa Rica); (3) Instituto de Investigación y Servicios Forestales, Universidad Nacional (INISEFOR-UNA), Heredia (Costa Rica); (4) Corporación de Desarrollo Agrícola Del Monte, S.A., 4084-1000 San José (Costa Rica); (5) GSA Consulting Group (Costa Rica); (6) Panamerican Woods S.A., San José (Costa Rica); (7) Ecoforest Panama S.A., Panama City (Panama)

@ Jesus Fernández-Moya (jesusfmoya@gmail.com)

Received: Jul 26, 2013 - Accepted: Feb 17, 2014

Citation: Fernández-Moya J, Murillo R, Portuguez E, Fallas JL, Ríos V, Kottman F, Verjans $J M$, Mata R, Alvarado A, 2015. Nutrient accumulation and export in teak (Tectona grandis L.f.) plantations of Central America. iForest 8: 33-44 [online 2014-06-04] URL: http://www. sisef.it/iforest/contents/?id=ifor1089-007

Communicated by: Giustino Tonon eas), of which 132780 ha are in Central America (3\%) and 86500 in Panama and Costa Rica (Kollert \& Cherubini 2012). In contrast to the rotations of 40-80 years used in Asia and Africa, in Central America the species is intensively managed in rotations of 20-25 years, usually in carefully selected productive sites, with an expected commercial industrial volume of $10 \mathrm{~m}^{3} \mathrm{ha}^{-1}$ year ${ }^{-1}$ (Pandey \& Brown 2000, De Camino et al. 2002). In this kind of short-rotation, intensively-managed forest plantations, nutrient management is a key issue for attaining sustainability and maintaining yields for future rotations (Poels 1994, Evans \& Turnbull 2004). Appropriate knowledge regarding teak nutrition is required to improve plantation management and to attain high productivity and sustainability.

Nutrient accumulation increases with the stand's age, mainly due to biomass accumulation; however, nutrient uptake during early years is considered crucial to sustain the high growth rates and the rapid expansion of both crown and roots required to maintain an appropriate nutritional status throughout the entire rotation length (Miller 1981, Laclau et al. 2003). In general, foliage is the tree tissue with the highest nutrient concentration and it is considered to contain $20-40 \%$ of total stand nutrients, while tree stems are assumed to have relatively low concentrations of nutrients (Miller 1984, 1995). However, the high amount of biomass accumulated in the tree stem makes it an important sink of nutrients. As a consequence, the loss of nutrients through wood removal at harvesting is a major cause of impoverishment of forest sites (Fölster \& Khanna 1997, Worrel \& Hampson 1997). While N, P and Mg are mainly accumulated in the tree stem, bark and roots are considered to be $\mathrm{Ca}$ sinks (Nwoboshi 1984). Nutrient uptake depends mainly on the species' demand and its ability to access nutrients, as well as the potential of the site (especially the soil) to supply nutrients. In calcareous soils in India, the most absorbed nutrients by teak were $\mathrm{Ca}>\mathrm{K}>\mathrm{N}>\mathrm{Mg}>\mathrm{P}$ $=\mathrm{S}$ (Negi et al. 1995), while they were $\mathrm{K}>$ $\mathrm{N}>\mathrm{Ca} \gg \mathrm{Mg} \geq \mathrm{P}$ in less fertile soils in Africa (Nwoboshi 1984) and N $>\mathrm{Ca}>\mathrm{K}>$ $\mathrm{Mg}>\mathrm{P}>\mathrm{Na}>\mathrm{S}>\mathrm{Cl}$ in a different study site in India (Kumar et al. 2009).

In order to understand the relationship between soil and forest nutrition, it has been long recognized that it is first necessary to evaluate the quantities of nutrients taken up by the growing forest and removed from the site during timber extraction (Rennie 1955). However, Fölster \& Khanna (1997) pointed out a traditional and general lack of concern of this problem in planted forests. Soil-plant relation research in agriculture has traditionally analyzed when, where, and at what rates nutrients are accumulated by plants in or- 


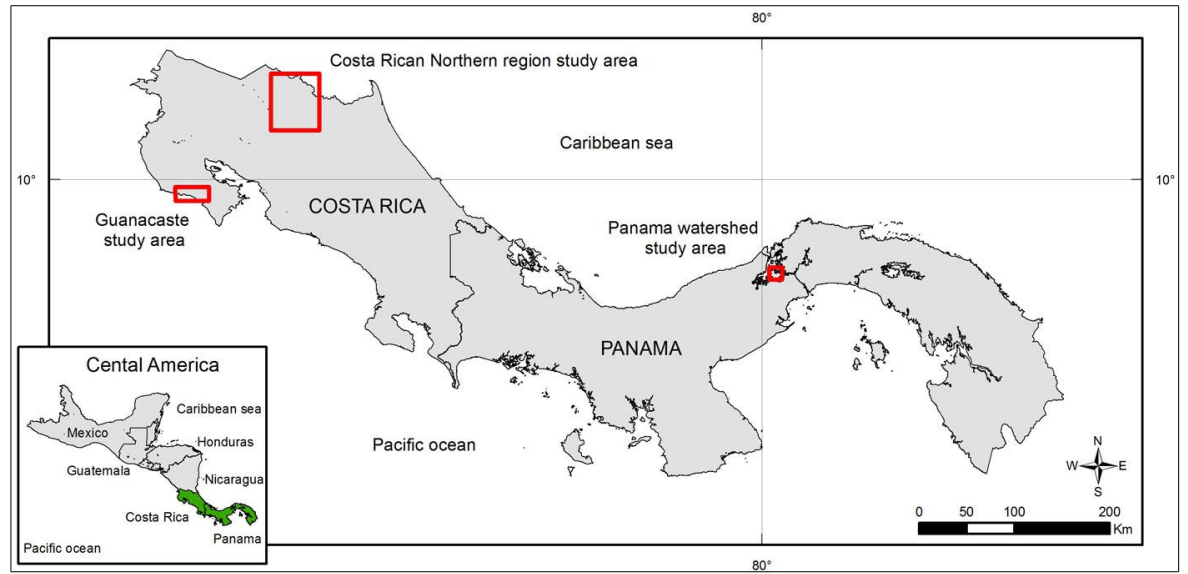

Fig. 1 - Locations of the study teak (Tectona grandis L.f.) plantations: Guanacaste (Costa Rica); northern region (Costa Rica) and Panama Canal Watershed (Panama).

der to accomplish an efficient and environmentally acceptable nutrient management (Sadler \& Karlen 1995, Bertsch 1998). Such kind of study on nutrient absorption curves or nutrient accumulation dynamics with age are traditionally used in agriculture and are considered as promising tools to analyze forest nutrition in intensively managed planted forests in the tropics (Ranger et al. 1995, Alvarado 2012a). In order to provide information for the near-maximum accumulation rates of any given crop, nutrient absorption studies are carried out in sites where nearmaximum yield of the crop is achieved (Sadler \& Karlen 1995, Bertsch 1998). By analyzing nutrient accumulation in the most productive soils without nutrient deficiencies (and in dominant or co-dominant trees in a site), the maximum species requirements are assessed. Therefore, if the minimum inputs calculated for these high-fertility sites are

applied in sites of lower fertility where tree nutrient uptake would be lower, the sustainability of the plantation is still achieved (Bertsch 1998, Alvarado 2012a).

Nutrient accumulation dynamics of a species can be used to estimate: (i) the nutrient removal by thinning or harvesting; (ii) the maximum nutrient absorption of the species over one rotation period; (iii) the amount of nutrients left at a site after harvesting, which will recycle and be reused during the next rotation; and (iv) the minimum nutrient inputs (fertilizers) the system requires to be sustainably managed (Ranger et al. 1995, Bertsch 1998, Alvarado 2012a).

To assess the nutrient sustainability of teak plantations, we conducted a study to measure the amount of nutrients accumulated by trees and exported during wood harvest, by analyzing the nutrient accumulation dynamics at different ages and the allocation pat-

Tab. 1 - Summary of topsoil $(0-20 \mathrm{~cm})$ properties at the different study sites. Means and coefficients of variation (in parentheses) are reported. Soil information was only available for 23 of the 28 sampled stands. (ECEC): effective cation exchange capacity. (AS): acidity saturation; $(*)$ : values outside the adequate reference soil levels (Bertsch 1998).

\begin{tabular}{|c|c|c|c|c|c|c|c|c|}
\hline \multirow{2}{*}{$\begin{array}{l}\text { Property } \\
\mathrm{pH}\end{array}$} & \multicolumn{2}{|c|}{$\begin{array}{l}\text { Northern region, } \\
\text { Costa Rica } \\
(n=11)\end{array}$} & \multicolumn{2}{|c|}{$\begin{array}{c}\text { Guanacaste, } \\
\text { Costa Rica } \\
(\mathrm{n}=9)\end{array}$} & \multicolumn{2}{|c|}{$\begin{array}{c}\text { Canal Zone, } \\
\text { Panama } \\
(\mathbf{n}=\mathbf{3})\end{array}$} & \multicolumn{2}{|c|}{$\begin{array}{c}\text { Total } \\
(\mathrm{n}=\mathbf{2 3})\end{array}$} \\
\hline & 5.11 & (6) & 5.9 & (6) & 6.7 & (12) & 5.63 & (12) \\
\hline Acidity $\left(\operatorname{cmol}(+) \mathrm{L}^{-1}\right)$ & $0.7^{*}$ & (5) & 0.31 & (30) & 0.15 & (33) & 0.48 & (81) \\
\hline $\mathrm{Ca}\left(\operatorname{cmol}(+) \mathrm{L}^{-1}\right)$ & 4.45 & (44) & 21.36 & (28) & 20.97 & (38) & 13.22 & (74) \\
\hline $\operatorname{Mg}\left(\operatorname{cmol}(+) L^{-1}\right)$ & 1.46 & (47) & 6.89 & (54) & 5.25 & (64) & 4.08 & (89) \\
\hline $\mathrm{K}\left(\operatorname{cmol}(+) \mathrm{L}^{-1}\right)$ & $0.13 *$ & (109) & 0.33 & (87) & 0.36 & (82) & 0.24 & (101) \\
\hline $\operatorname{ECEC}\left(\operatorname{cmol}(+) \mathrm{L}^{-1}\right)$ & 6.74 & (31) & 28.9 & (32) & 26.72 & (40) & 18.02 & (71) \\
\hline $\operatorname{AS}(\%)$ & $11.96^{*}$ & (84) & 1.22 & (58) & 0.65 & (55) & $6.28 *$ & (139) \\
\hline $\mathrm{P}\left(\mathrm{mg} \mathrm{L}^{-1}\right)$ & $3 *$ & (114) & $3^{*}$ & $(146)$ & $2 *$ & $(0)$ & $3 *$ & (124) \\
\hline $\mathrm{Zn}\left(\mathrm{mg} \mathrm{L}^{-1}\right)$ & $2 *$ & $(84)$ & 3 & $(58)$ & 3 & $(107)$ & $2 *$ & (77) \\
\hline $\mathrm{Cu}\left(\mathrm{mg} \mathrm{L}^{-1}\right)$ & 8 & (19) & 11 & (85) & 4 & $(83)$ & 9 & (71) \\
\hline $\mathrm{Fe}\left(\mathrm{mg} \mathrm{L}^{-1}\right)$ & 165 & (23) & 37 & (81) & 65 & (154) & 102 & (75) \\
\hline $\operatorname{Mn}\left(\mathrm{mg} \mathrm{L}^{-1}\right)$ & 43 & $(171)$ & 38 & (82) & 19 & (101) & 38 & (142) \\
\hline Organic matter $(\%)$ & 4.6 & $(27)$ & 3.8 & (28) & 4.6 & (16) & 4.3 & (27) \\
\hline Sand $(\%)$ & 24.9 & (23) & 23.4 & (56) & 29 & (31) & 24.8 & (38) \\
\hline Silt $(\%)$ & 18.4 & (13) & 36.9 & (42) & 36.8 & (43) & 28 & (51) \\
\hline Clay $(\%)$ & 56.7 & (11) & 39.7 & (22) & 34.3 & (50) & 47.1 & (27) \\
\hline
\end{tabular}

terns in highly productive teak plantations in Central America (Costa Rica and Panama) throughout a rotation period.

\section{Material and methods}

\section{Study sites}

Three teak (Tectona grandis L.f.) plantations were studied in Central America: two in Costa Rica (Guanacaste and northern region) and one in Panama (Panama Canal watershed - Fig. 1). The three areas are classified as tropical wet forest according to Holdridge's life zones (Holdridge 1947), with similar mean annual rainfall (2500$3100 \mathrm{~mm}$ ), although in Guanacaste the dry season lasts longer than at the other two sites. The soils in the study areas are also similar, although the northern region of Costa Rica is less fertile and has higher soil acidity than the other sites (Tab. 1).

The stands studied were chosen to be representative of properly managed teak plantations in Central America. In general, their management consists on continuous silvicultural activities: weed control, pruning, thinning regimen (approximately from $800-1000$ trees $\mathrm{ha}^{-1}$ at establishment to $150-200$ trees $\mathrm{ha}^{-1}$ at final felling) and fertilization during the establishment. The use of clones is common in recent years. An expected commercial volume of $100-150 \mathrm{~m}^{3} \mathrm{ha}^{-1}$ is expected for this kind of plantation after approximately 20 years rotation.

\section{Field sampling and design}

A false time-series (chronosequences) method was used to analyze nutrient accumulation dynamics of teak trees from age 1 to 19 years. Johnson \& Miyanishi (2008) define such method as an inference of a time sequence of development made from a series of plots or stands differing in age. Despite of the critiques to this method (Johnson \& Miyanishi 2008), it is considered a valid methodology as far as all studied stands grow under similar environmental conditions (soil and climate) and are subject to similar management practices. Hence, stands of different ages (between 1 and 19 years old) were studied, assuming that they represent the average time-pattern of the plantations analyzed. A total of 28 stands were analyzed, seven in Panama, 12 in the northern region of Costa Rica and nine in Guanacaste (Costa Rica). In order to set up a maximum yield research experiment (Sadler \& Karlen 1995, Bertsch 1998, Alvarado 2012a), dominant and codominant trees were selected: (a) with no visible symptoms of diseases or nutritional deficiencies; and (b) that were representative of the best-performing trees of the plantations, assuming optimal nutrition and a full expression of genetic potential. In stands of age $<10$ years, two trees were sampled per stand, whereas only one tree was sam- 
Tab. 2 - Summary of nutrient concentration age dynamics in 1 to 19 years old teak (Tectona grandis L.f.) plantations in Costa Rica and Panama (Fernández-Moya et al. 2013). Macronutrient concentration (N, Ca, K, Mg, P and S) is expressed in \%, while micronutrient concentration $(\mathrm{Fe}, \mathrm{Mn}, \mathrm{Cu}, \mathrm{Zn}$ and $\mathrm{B})$ is expressed in $\mathrm{mg} \mathrm{kg}^{-1}$. Nutrient estimations and confidence intervals $(\alpha=0.05)$ are reported. $(*)$ : When no correlation was found between tree age and nutrient concentration in the compartment considered, concentration value is given only for 10 years old trees.

\begin{tabular}{|c|c|c|c|c|c|c|}
\hline \multirow{2}{*}{ Nutrient } & \multicolumn{3}{|c|}{ Bole } & \multicolumn{3}{|c|}{ Bark } \\
\hline & 5 years & 10 years & 19 years & 5 years & 10 years & 19 years \\
\hline $\mathrm{N}$ & 0.33 & 0.29 & 0.24 & 0.69 & 0.61 & 0.51 \\
\hline & $(0.29-0.41)$ & $(0.25-0.36)$ & $(0.20-0.30)$ & $(0.62-0.79)$ & $(0.54-0.71)$ & $(0.45-0.61)$ \\
\hline $\mathrm{Ca}$ & - & $\begin{array}{c}0.11 \\
(0.10-0.12)^{*}\end{array}$ & - & - & $\begin{array}{c}1.91 \\
(1.44-2.38)^{*}\end{array}$ & - \\
\hline K & $\begin{array}{c}0.25 \\
(0.19-0.33)\end{array}$ & $\begin{array}{c}0.15 \\
(0.09-0.23)\end{array}$ & $\begin{array}{c}0.03 \\
(0.01-0.11)\end{array}$ & $\begin{array}{c}1.33 \\
(1.08-1.60)\end{array}$ & $\begin{array}{c}1.04 \\
(0.74-1.40)\end{array}$ & $\begin{array}{c}0.63 \\
(0.32-1.09)\end{array}$ \\
\hline $\mathrm{Mg}$ & $\begin{array}{c}0.09 \\
(0.08-0.13)\end{array}$ & $\begin{array}{c}0.07 \\
(0.06-0.10)\end{array}$ & $\begin{array}{c}0.05 \\
(0.04-0.07)\end{array}$ & - & $\begin{array}{c}0.23 \\
(0.22-0.25)^{*}\end{array}$ & $\frac{-}{(0.02-1.07)}$ \\
\hline $\mathrm{P}$ & - & $\begin{array}{c}0.06 \\
(0.03-0.10)^{*}\end{array}$ & - & - & $\begin{array}{c}0.08 \\
(0.06-0.10)^{*}\end{array}$ & - \\
\hline $\mathrm{S}$ & - & $\begin{array}{c}0.04 \\
(0.03-0.06)^{*}\end{array}$ & - & $\begin{array}{c}0.07 \\
(0.06-0.08)\end{array}$ & $\begin{array}{c}0.06 \\
(0.05-0.07)\end{array}$ & $\begin{array}{c}0.05 \\
(0.04-0.06)\end{array}$ \\
\hline $\mathrm{Fe}$ & - & $\begin{array}{c}72.46 \\
(27.37-117.56)^{*}\end{array}$ & - & $\begin{array}{c}268.81 \\
(152.15-348.39)\end{array}$ & $\begin{array}{c}216.17 \\
(0.01-325.69)\end{array}$ & $\begin{array}{c}27.88 \\
(0.01-280.24)\end{array}$ \\
\hline $\mathrm{Mn}$ & - & $\begin{array}{c}1.25 \\
(0.64-1.86)^{*}\end{array}$ & - & $\begin{array}{c}26.73 \\
(18.99-188.98)\end{array}$ & $\begin{array}{c}20.41 \\
(14.51-144.34)\end{array}$ & $\begin{array}{c}15.43 \\
(10.97-109.11)\end{array}$ \\
\hline $\mathrm{Cu}$ & - & $\begin{array}{c}2.09 \\
(1.56-2.62)^{*}\end{array}$ & - & - & $\begin{array}{c}3.46 \\
(2.86-4.06)^{*}\end{array}$ & - \\
\hline $\mathrm{Zn}$ & - & $\begin{array}{c}10.34 \\
(1.68-18.99)^{*}\end{array}$ & - & - & $\begin{array}{c}29.85 \\
(20.84-38.85)^{*}\end{array}$ & - \\
\hline B & - & $\begin{array}{c}2.71 \\
(2.17-3.26)^{*}\end{array}$ & - & - & $\begin{array}{c}30.66 \\
(28.34-32.98)^{*}\end{array}$ & - \\
\hline \multirow{2}{*}{ Nutrient } & \multicolumn{3}{|c|}{ Foliage } & \multicolumn{3}{|c|}{ Branches } \\
\hline & 5 years & 10 years & 19 years & 5 years & 10 years & 19 years \\
\hline $\mathrm{N}$ & $\begin{array}{c}2.13 \\
(1.97-2.33)\end{array}$ & $\begin{array}{c}1.97 \\
(1.83-2.15)\end{array}$ & $\begin{array}{c}1.76 \\
(1.64-1.91)\end{array}$ & $\begin{array}{c}0.52 \\
(0.45-0.65)\end{array}$ & $\begin{array}{c}0.45 \\
(0.39-0.56)\end{array}$ & $\begin{array}{c}0.37 \\
(0.32-0.46)\end{array}$ \\
\hline $\mathrm{Ca}$ & 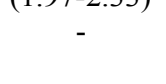 & $\begin{array}{c}1.34 \\
(1.13-1.54)^{*}\end{array}$ & $\frac{-}{(1.07-10)}$ & $\begin{array}{c}-(0.70-0.00) \\
-\end{array}$ & $\begin{array}{c}0.91 \\
(0.81-1.02)^{*}\end{array}$ & $\begin{array}{c}-0.00) \\
-\end{array}$ \\
\hline K & - & $\begin{array}{c}0.88 \\
(0.73-1.02)^{*}\end{array}$ & - & - & $\begin{array}{c}0.43 \\
(0.34-0.52)^{*}\end{array}$ & - \\
\hline $\mathrm{Mg}$ & $\begin{array}{c}0.26 \\
(0.18-0.31)\end{array}$ & $\begin{array}{c}0.29 \\
(0.22-0.34)\end{array}$ & $\begin{array}{c}0.34 \\
(0.27-0.39)\end{array}$ & $\begin{array}{c}0.15 \\
(0.13-0.17)\end{array}$ & $\begin{array}{c}0.12 \\
(0.11-0.13)\end{array}$ & $\begin{array}{c}0.09 \\
(0.08-0.10)\end{array}$ \\
\hline$P$ & $\begin{array}{c}-10.10-01) \\
-\end{array}$ & $\begin{array}{c}0.16 \\
(0.12-0.20)^{*}\end{array}$ & $\begin{array}{c}(0.21-0.07) \\
-\end{array}$ & $\begin{array}{c}-10.17) \\
-\end{array}$ & $\begin{array}{c}0.08 \\
(0.03-0.12)^{*}\end{array}$ & $\begin{array}{c}(0.00-0.10) \\
-\end{array}$ \\
\hline S & - & $\begin{array}{c}0.12 \\
(0.11-0.13)^{*}\end{array}$ & - & - & $\begin{array}{c}0.07 \\
(0.05-0.08)^{*}\end{array}$ & - \\
\hline $\mathrm{Fe}$ & - & $\begin{array}{c}129.61 \\
(84.63-174.59)^{*}\end{array}$ & - & - & $\begin{array}{c}162.76 \\
(145.68-179.83)^{*}\end{array}$ & - \\
\hline $\mathrm{Mn}$ & - & $\begin{array}{c}42.55 \\
(39.03-46.07) *\end{array}$ & - & - & $\begin{array}{c}13.93 \\
(11.50-16.37)^{*}\end{array}$ & - \\
\hline $\mathrm{Cu}$ & - & $\begin{array}{c}11.08 \\
(10.22-11.93)^{*}\end{array}$ & - & $\begin{array}{c}5.23 \\
(4.41-6.80)\end{array}$ & $\begin{array}{c}3.56 \\
(3.11-4.29)\end{array}$ & $\begin{array}{c}2.54 \\
(2.25-2.97)\end{array}$ \\
\hline $\mathrm{Zn}$ & - & $\begin{array}{c}32.00 \\
(24.74-39.26)^{*}\end{array}$ & - & $\begin{array}{c}21.34 \\
(15.22-29.93)\end{array}$ & $\begin{array}{c}15.44 \\
(10.10-23.6)\end{array}$ & $\begin{array}{c}8.61 \\
(4.82-15.38)\end{array}$ \\
\hline B & - & $\begin{array}{c}19.62 \\
(18.32-20.91)^{*}\end{array}$ & - & - & $\begin{array}{c}13.93 \\
(11.50-16.37)^{*}\end{array}$ & - \\
\hline
\end{tabular}

pled in older stands. Trees were felled and biomass accumulated at different tree components (bole, bole's bark, foliage and primary and secondary branches) was weighed in the field. A random subsample $(1 \mathrm{~kg}$ per component per tree) was then collected taking care of its representativeness of the whole sample of each component and tree (for more details see Fernández-Moya et al.
2013). Dry biomass (hereafter biomass) was then calculated based on field measurements and sample water content estimated in laboratory. All the fieldwork was performed during July- September, at the tree's optimal nutritional status during the period of maximum growth activity, to avoid effects of seasonality.

Tissues samples were analyzed at the Cen- tro de Investigaciones Agronómicas of the University of Costa Rica (hereafter CIAUCR) to determine nutrient concentrations (N, P, Ca, Mg, K, S, Fe, Mn, Cu, Zn and B, hereafter referred to as nutrients) after samples were dried and water content was assessed. Dry combustion was used to measure the $\mathrm{N}$ concentration, and wet digestion and atomic spectrometry were used to extract and 
Tab. 3 - Relationship between biomass accumulation $(\mathrm{kg})$ and tree age (years) in 1 to 19 years old teak (Tectona grandis L.f.) plantations in Costa Rica and Panama. The models reported are in the form $\left[y=\left(b_{1} \cdot a g e\right)^{1 / \lambda}\right]$, where the response variable $(y)$ is the biomass accumulation in the different tree compartments. EF (\%): Model efficiency, pseudo $\mathrm{R}^{2}$ estimate for Generalized Linear Mixed Models (see text for more details). $(*)$ : Biomass estimates obtained by the models at different ages (confidence intervals are reported in parentheses, $\alpha=0.05$ ).

\begin{tabular}{|c|c|c|c|c|c|c|c|c|c|c|}
\hline \multirow{3}{*}{ Tissues } & \multirow{2}{*}{\multicolumn{4}{|c|}{ Model }} & \multicolumn{6}{|c|}{ Biomass accumulation } \\
\hline & & & & & \multicolumn{2}{|c|}{5 years } & \multicolumn{2}{|c|}{10 years } & \multicolumn{2}{|c|}{19 years } \\
\hline & $\mathbf{b}_{1}$ & $\begin{array}{c}\mathbf{b}_{1} \\
\text { (SE) }\end{array}$ & $\lambda$ & $\begin{array}{l}\text { EF } \\
(\%)\end{array}$ & kg* & $\begin{array}{l}\text { \% of } \\
\text { Total }\end{array}$ & kg* & $\begin{array}{l}\text { \%o of } \\
\text { Total }\end{array}$ & $\mathbf{k g} *$ & $\begin{array}{l}\text { \% of } \\
\text { Total }\end{array}$ \\
\hline Foliage & 30.515 & 0.2845 & 1.2 & 69 & $\begin{array}{c}10 \\
(8-11)\end{array}$ & 11.1 & $\begin{array}{c}17 \\
(15-20)\end{array}$ & 6.2 & $\begin{array}{c}29 \\
(25-34)\end{array}$ & 3.7 \\
\hline Bark & 10.461 & 0.0258 & 0.8 & 49 & $\begin{array}{c}8 \\
(7-8)\end{array}$ & 9.1 & $\begin{array}{c}19 \\
(18-20)\end{array}$ & 6.8 & $\begin{array}{c}42 \\
(39-45)\end{array}$ & 5.2 \\
\hline Bole & 21.629 & 0.1062 & 0.6 & 91 & $\begin{array}{c}53 \\
(45-62)\end{array}$ & 60.7 & $\begin{array}{c}168 \\
(142-196)\end{array}$ & 60.7 & $\begin{array}{c}489 \\
(413-570)\end{array}$ & 60.7 \\
\hline $\begin{array}{l}\text { Bole } \\
\text { and bark }\end{array}$ & 23.399 & 0.1032 & 0.6 & 91 & $\begin{array}{c}60 \\
(52-69)\end{array}$ & 69.1 & $\begin{array}{c}191 \\
(165-220)\end{array}$ & 69.1 & $\begin{array}{c}558 \\
(480-641)\end{array}$ & 69.1 \\
\hline Branches & 0.8106 & 0.0423 & 0.5 & 82 & $\begin{array}{c}16 \\
(13-20)\end{array}$ & 18.8 & $\begin{array}{c}66 \\
(53-80)\end{array}$ & 23.7 & $\begin{array}{c}237 \\
(191-288)\end{array}$ & 29.4 \\
\hline Total & 29.196 & 0.1275 & 0.6 & 91 & $\begin{array}{c}87 \\
(75-100)\end{array}$ & - & $\begin{array}{c}277 \\
(238-317)\end{array}$ & - & $\begin{array}{c}807 \\
(695-925)\end{array}$ & - \\
\hline
\end{tabular}

determine other nutrients (Bertsch 1998). Tab. 2 summarizes nutrient concentration age dynamics (for more details see Fernández-Moya et al. 2013).

Nutrient accumulation and allocation in tissues biomass were the target variables of this work, and were calculated by multiplying nutrient concentration (as reported in Tab. 2) by biomass (Fernández-Moya et al. 2013).
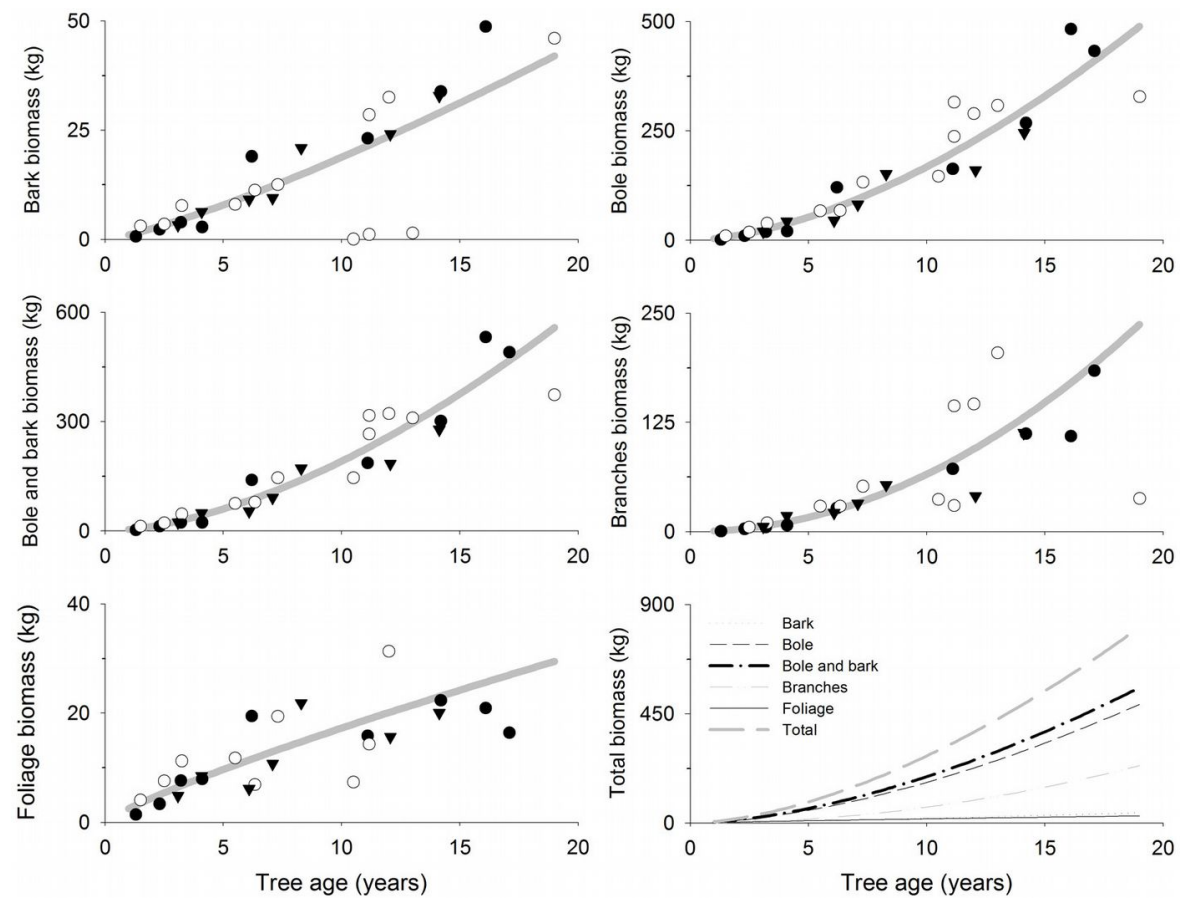

Fig. 2 - Biomass accumulation $\left(\mathrm{kg}_{\text {tree }} \mathrm{e}^{-1}\right.$ or $\mathrm{g}$ tre $\left.\mathrm{e}^{-1}\right)$ in different tree compartments related to tree age (years) in teak plantations (Tectona grandis L.f.). Points represent sampled trees at three different locations: Guanacaste, Costa Rica (black circles); Northern Region, Costa Rica (white circles); Panama (black triangles). Lines represent the fitted models reported in Tab. 3 . ches, respectively, $N_{\mathrm{i}[\mathrm{pbr}]}$ and $N_{\mathrm{i}[\mathrm{sbr}]}$ are the concentration of the $i$-th nutrient in primary and secondary branches, respectively. Bole and bark nutrient accumulation were also weighted averaged (reported henceforth as "bole and bark" - eqn. 2):

$$
N_{i-a c c(b b)}=\frac{B_{b l} N_{i[b l]}+B_{b k} N_{i[b k]}}{B_{b l}+B_{b k}}
$$

where $N_{\mathrm{i} \text {-acc(bb) }}$ is the nutrient accumulation in bole and bark of the $i$-th nutrient, $B_{\mathrm{b} 1}$ and $B_{\mathrm{bk}}$ are the biomass of bole and bark, respectively, $N_{\mathrm{i}[\mathrm{bl}]}$ and $N_{\mathrm{i}[\mathrm{bk}]}$ are the concentration of the $i$-th nutrient in the bole and in the bark, respectively. Similarly, "total" nutrient accumulation represents a weighted average from all the sampled tissues.

No detailed information about the thinning regime of the studied stands nor the dynamics of tree density with age were available. In order to upscale individual tree measurements to estimate stand's values, tree stocking at different stands age were considered as 1000,300 and 150 trees $^{-1}$ at 1-5, 10 and 19 years, respectively. These values are considered as average values normally used in plantations in Central America. Although plant density may influence tree nutrient uptake because of competition for soil nutrients, we consider plant density for a given age as relatively homogeneous between the three study sites, as the three companies follow similar management patterns.

In order to estimate soil nutrient availability, topsoil samples were collected $(0-20$ $\mathrm{cm})$, where more than half of the teak roots are situated (Srivastava et al. 1986, Behling 2009). Five soil sub-samples were taken from each site (without litter) and pooled into one composed soil sample for each site. Soil information was only available for 23 of the 28 sampled stands (Tab. 1). Soil samples were collected simultaneously to the biomass collection described above. Soil samples were analyzed at CIA-UCR to determine: $\mathrm{pH}, \mathrm{Ca}, \mathrm{Mg}, \mathrm{K}$, acidity and $\mathrm{Al}, \mathrm{P}, \mathrm{Fe}, \mathrm{Cu}$, $\mathrm{Zn}, \mathrm{Mn}$. $\mathrm{pH}$ was determined in water 10:25; acidity, $\mathrm{Al}, \mathrm{Ca}$ and $\mathrm{Mg}$ in $\mathrm{KCl}$ solution $1 \mathrm{M}$ $1: 10 ; \mathrm{P}, \mathrm{K}, \mathrm{Zn}, \mathrm{Fe}, \mathrm{Mn}$ and $\mathrm{Cu}$ in modified Olsen solution $\mathrm{pH} \quad 8.5\left(\mathrm{NaHCO}_{3} \quad 0.5 \mathrm{~N}\right.$, EDTA 0.01M, Superfloc 127) 1:10. Organic matter was determined by the combustion method described by Horneck \& Miller (1998). Soil texture was determined using the modified Bouyoucos method, as described by Forsythe (1975).

Teak roots accounts for $5-30 \%$ of total tree nutrient accumulation (Ola-Adams 1993 , Siddiqui et al. 2007, Behling 2009) so total planted teak forests accumulation can be estimated as $105-130 \%$ of the above mentioned for the aboveground biomass. Belowground biomass was not taken into account in this study because it is left at the site after final harvesting, mineralized and used by the next rotation (recycled). 
Tab. 4 - Results of the regression analysis between nutrient accumulation in the different tree compartments and tree age (years) in 1 to 19 years old teak (Tectona grandis L.f.) plantations in Costa Rica and Panama. The models reported are in the form $\left[y=\left(b_{0}+b_{1} \cdot a g e\right)^{1 / \lambda}\right]$, where the response variable $(y)$ is the nutrient accumulation in the different tree tissues. When no model including age as a parameter was statistically significant, only an intercept $\left(b_{0}\right)$ representing the mean of the variable was included in the model. EF (\%): Model efficiency, pseudo $\mathrm{R}^{2}$ estimate for Generalized Linear Mixed Models (see text for more details).

\begin{tabular}{|c|c|c|c|c|c|c|c|c|c|c|c|c|}
\hline \multirow[b]{2}{*}{ Tissues } & \multicolumn{6}{|c|}{ Macronutrient (kg) } & \multicolumn{6}{|c|}{ Micronutrient (g) } \\
\hline & Element & $b_{0}$ & $b_{1}$ & $b_{1 \text { [Std. error] }}$ & $\lambda$ & EF (\%) & Element & $b_{0}$ & $b_{1}$ & $b_{1 \text { [Std. error] }}$ & $\lambda$ & EF (\%) \\
\hline \multirow[t]{6}{*}{ Foliage } & $\mathrm{N}$ & - & 0.0218 & 0.0022 & 1.4 & 55 & $\mathrm{Fe}$ & - & 0.2088 & 0.0149 & 0.9 & 66 \\
\hline & $\mathrm{Ca}$ & - & 0.0205 & 0.0003 & 1.1 & 66 & $\mathrm{Mn}$ & - & 0.0522 & 0.0100 & 1.6 & 39 \\
\hline & $\mathrm{K}$ & - & 0.0018 & 0.0002 & 2.0 & 41 & $\mathrm{Cu}$ & - & 0.0062 & 0.0011 & 1.4 & 47 \\
\hline & $\mathrm{Mg}$ & - & 0.0049 & 0.0004 & 1.0 & 74 & $\mathrm{Zn}$ & - & 0.0452 & 0.0029 & 1.3 & 60 \\
\hline & $\mathrm{P}$ & - & 0.0009 & 0.0001 & 1.3 & 63 & $\mathrm{~B}$ & - & 0.0240 & 0.0040 & 1.3 & 60 \\
\hline & $\mathrm{S}$ & - & 0.0006 & 0.0001 & 1.3 & 58 & - & - & - & - & - & - \\
\hline \multirow[t]{6}{*}{ Bark } & $\mathrm{N}$ & - & 0.0186 & 0.0002 & 0.8 & 43 & $\mathrm{Fe}$ & - & 0.4200 & 0.084 & 1.2 & 23 \\
\hline & $\mathrm{Ca}$ & - & 0.0545 & 0.0041 & 0.5 & 47 & $\mathrm{Mn}$ & - & 0.0352 & 0.0019 & 1.1 & 33 \\
\hline & $\mathrm{K}$ & - & 0.0109 & 0.0011 & 1.2 & 35 & $\mathrm{Cu}$ & - & 0.0081 & 0.0010 & 0.7 & 39 \\
\hline & $\mathrm{Mg}$ & - & 0.0054 & 0.0002 & 0.9 & 43 & $\mathrm{Zn}$ & - & 0.0564 & 0.0073 & 0.9 & 39 \\
\hline & $\mathrm{P}$ & 0.0116 & - & - & - & - & B & - & 0.0632 & 0.0026 & 0.6 & 50 \\
\hline & $\mathrm{S}$ & - & 0.0017 & 0.0001 & 0.9 & 43 & - & - & - & - & - & - \\
\hline \multirow[t]{6}{*}{ Bole } & $\mathrm{N}$ & - & 0.0574 & 0.0028 & 0.7 & 89 & $\mathrm{Fe}$ & - & 0.4318 & 0.0751 & 0.6 & 51 \\
\hline & $\mathrm{Ca}$ & - & 0.0354 & 0.0014 & 0.6 & 90 & $\mathrm{Mn}$ & 0.0960 & - & - & - & - \\
\hline & $\mathrm{K}$ & - & 0.0079 & 0.0013 & 1.6 & 45 & $\mathrm{Cu}$ & - & 0.0434 & 0.0045 & 0.5 & 71 \\
\hline & $\mathrm{Mg}$ & - & 0.0236 & 0.0012 & 0.7 & 82 & $\mathrm{Zn}$ & 0.9382 & - & - & - & - \\
\hline & $\mathrm{P}$ & 0.1133 & - & - & - & - & B & - & 0.0526 & 0.0060 & 0.7 & 75 \\
\hline & S & - & 0.0209 & 0.0038 & 0.6 & 67 & - & - & - & - & - & - \\
\hline \multirow{6}{*}{$\begin{array}{l}\text { Bole } \\
\text { and bark }\end{array}$} & $\mathrm{N}$ & - & 0.0688 & 0.0027 & 0.7 & 89 & $\mathrm{Fe}$ & - & 0.500 & 0.0575 & 0.6 & 60 \\
\hline & $\mathrm{Ca}$ & - & 0.0767 & 0.0018 & 0.6 & 82 & $\mathrm{Mn}$ & - & 0.0447 & 0.0009 & 1.1 & 45 \\
\hline & $\mathrm{K}$ & - & 0.0265 & 0.0052 & 1.3 & 52 & $\mathrm{Cu}$ & - & 0.043 & 0.005 & 0.6 & 53 \\
\hline & $\mathrm{Mg}$ & - & 0.0288 & 0.0016 & 0.7 & 84 & $\mathrm{Zn}$ & 13.757 & - & - & - & - \\
\hline & $\mathrm{P}$ & 0.1249 & - & - & - & - & B & - & 0.0949 & 0.0062 & 0.6 & 77 \\
\hline & $\mathrm{S}$ & - & 0.0234 & 0.0037 & 0.6 & 72 & - & - & - & - & - & - \\
\hline \multirow[t]{6}{*}{ Branches } & $\mathrm{N}$ & - & 0.0412 & 0.0023 & 0.7 & 71 & $\mathrm{Fe}$ & - & 0.3773 & 0.0108 & 0.6 & 63 \\
\hline & $\mathrm{Ca}$ & - & 0.0761 & 0.0052 & 0.5 & 83 & $\mathrm{Mn}$ & - & 0.0836 & 0.0083 & 0.6 & 62 \\
\hline & $\mathrm{K}$ & - & 0.0401 & 0.0032 & 0.7 & 73 & $\mathrm{Cu}$ & - & 0.0274 & 0.0023 & 0.8 & 66 \\
\hline & $\mathrm{Mg}$ & - & 0.0210 & 0.0012 & 0.6 & 80 & $\mathrm{Zn}$ & - & 0.0910 & 0.0104 & 0.7 & 58 \\
\hline & $\mathrm{P}$ & 0.0391 & - & - & - & - & B & - & 0.0753 & 0.0044 & 0.6 & 80 \\
\hline & S & - & 0.0142 & 0.0016 & 0.6 & 73 & - & - & - & - & - & - \\
\hline \multirow[t]{6}{*}{ Total } & $\mathrm{N}$ & - & 0.1165 & 0.0044 & 0.8 & 87 & $\mathrm{Fe}$ & - & 0.9331 & 0.0742 & 0.7 & 72 \\
\hline & $\mathrm{Ca}$ & - & 0.1281 & 0.0024 & 0.6 & 91 & $\mathrm{Mn}$ & - & 0.2045 & 0.0144 & 1.2 & 54 \\
\hline & $\mathrm{K}$ & - & 0.0676 & 0.0091 & 1.3 & 93 & $\mathrm{Cu}$ & - & 0.0711 & 0.0085 & 0.8 & 68 \\
\hline & $\mathrm{Mg}$ & - & 0.0425 & 0.0013 & 0.7 & 89 & $\mathrm{Zn}$ & - & 0.2692 & 0.0608 & 0.9 & 53 \\
\hline & $\mathrm{P}$ & 0.02180 & - & - & - & - & B & - & 0.1657 & 0.0060 & 0.6 & 85 \\
\hline & $\mathrm{S}$ & - & 0.0254 & 0.0033 & 0.7 & 82 & - & - & - & - & - & - \\
\hline
\end{tabular}

\section{Statistical analysis}

Generalized linear mixed models (henceforth: GLMMs) were used to study the relationships between nutrient (N, P, Ca, Mg, K, $\mathrm{S}, \mathrm{Fe}, \mathrm{Mn}, \mathrm{Cu}, \mathrm{Zn}$ and $\mathrm{B}$ ) accumulation in each tissue (bole, bark, bole and bark, branches, foliage and total) and tree age. The use of GLMMs was necessary as most of the study variables did not follow the normal distribution assumed for traditional models. The probability distribution of each of the 72 response variables analyzed was studied prior to construct the GLMMs. The exponentially distributed variables were modeled using a Gamma distribution approach with $\alpha=1$.

To evaluate the most suitable model for each study variable, a total of 83 different models were constructed, selecting the one with lowest deviance. Three groups of mo- dels were constructed: (1) a null model considering only an intercept $\left[y_{\mathrm{i}}=\mathrm{b}_{0}\right]$; (2) a model considering an intercept in addition to age as an explanatory variable $\left[y_{\mathrm{i}}^{\lambda}=\right.$ age + $\left.\mathrm{b}_{0}\right]$; and (3) a model without an intercept $\left[y_{i}^{\lambda}\right.$ $=$ age]. For groups (2) and (3), 41 different power link functions $\left[\mathrm{g}(\mu)=\mu^{\lambda}\right]$ were tested for each one, with $\lambda$ varying between $\lambda=2$ to $\lambda=-2$ and a $\lambda_{\text {gap }}=0.1$. When no model including age as a parameter was statistically significant, or when the data did not follow any of the studied distribution functions, the resulting model included only an intercept representing the mean of the variable, and no age effect was taken into account.

The sampled stands in each study area were spatially correlated. The spatial correlation was taken into account by including a random effect for the study area, modeling the working correlation matrix with a first-order autoregressive structure. The goodness-of-fit of the models was assessed by measuring the percentage difference between the deviance of the model and the deviance of a model with no covariates (hereafter referred to as efficiency: EF), which is a pseudo- $\mathrm{R}^{2}$ measure reported for GLMMs. All statistical analyses were performed using SAS 9.0 (SAS Institute Inc 2002). All statistical tests throughout the text are considered significant with $\alpha=0.05$.

\section{Results}

\section{Aboveground biomass allocation}

The fitted models showed an estimated total aboveground biomass of 87, 277 and 807 $\mathrm{kg}$ at 5,10 and 19 years old, respectively (Tab. 3, Fig. 2). Bole was the tissue where most biomass accumulated, accounting for 
Tab. 5 - Nutrient accumulation in 1 to 19 years old teak (Tectona grandis L.f.) plantations in Costa Rica and Panama. Total nutrient accumulation is estimated from the statistical models summarized in Tab. 4 and represents the sum of the nutrients accumulated in bole, bark, branches and foliage. Individual tree estimations (Tab. 4) were used to calculate the stand values, assuming the following densities: 1000, 300 and 150 trees ha ${ }^{-1}$ at $1-5,10$ and 19 years respectively. $(*)$ : Nutrient estimates obtained by the models at different ages (confidence intervals are in parentheses, $\alpha=0.05)$. (**): No statistically sound model could be fitted between total $\mathrm{P}$ accumulation and age (Tab. 4); therefore, estimated $\mathrm{P}$ accumulation is based in the average from the sampled trees; all collected data was taken into account, no difference could be made based on tree age.

\begin{tabular}{|c|c|c|c|c|c|c|}
\hline \multirow{2}{*}{ Nutrient } & \multicolumn{2}{|c|}{$5 \mathrm{yr}$} & \multicolumn{2}{|c|}{$10 \mathrm{yr}$} & \multicolumn{2}{|c|}{$19 \mathrm{yr}$} \\
\hline & nutrient tree $e^{-1 *}$ & nutrient ha $^{-1}$ & nutrient tree ${ }^{-1}$ * & nutrient $\mathrm{ha}^{-1}$ & nutrient tree $e^{-1}$ * & nutrient $\mathrm{ha}^{-1}$ \\
\hline $\mathrm{N}(\mathrm{kg})$ & $\begin{array}{c}0.51 \\
(0.46-0.56)\end{array}$ & 508.89 & $\begin{array}{c}1.21 \\
(1.10-1.32)\end{array}$ & 363.10 & $\begin{array}{c}2.70 \\
(2.45-2.95)\end{array}$ & 404.99 \\
\hline $\mathrm{Ca}(\mathrm{kg})$ & $\begin{array}{c}0.48 \\
(0.45-0.51)\end{array}$ & 475.92 & $\begin{array}{c}1.51 \\
(1.42-1.60)\end{array}$ & 453.28 & $\begin{array}{c}4.40 \\
(4.14-4.68)\end{array}$ & 660.59 \\
\hline $\mathrm{K}(\mathrm{kg})$ & $\begin{array}{c}0.43 \\
(0.34-0.52)\end{array}$ & 434.14 & $\begin{array}{c}0.74 \\
(0.58-0.89)\end{array}$ & 221.98 & $\begin{array}{c}1.21 \\
(0.96-1.45)\end{array}$ & 181.85 \\
\hline $\operatorname{Mg}(\mathrm{kg})$ & $\begin{array}{c}0.11 \\
(0.10-0.12)\end{array}$ & 109.42 & $\begin{array}{c}0.29 \\
(0.27-0.32)\end{array}$ & 88.36 & $\begin{array}{c}0.74 \\
(0.67-0.80)\end{array}$ & 110.52 \\
\hline $\mathrm{P}^{* *}(\mathrm{~kg})$ & 0.22 & 217.97 & 0.22 & 65.39 & 0.22 & 32.70 \\
\hline $\mathrm{S}(\mathrm{kg})$ & $\begin{array}{c}0.05 \\
(0.03-0.07)\end{array}$ & 52.45 & $\begin{array}{c}0.14 \\
(0.09-0.20)\end{array}$ & 42.35 & $\begin{array}{c}0.35 \\
(0.23-0.49)\end{array}$ & 52.98 \\
\hline $\mathrm{Fe}(\mathrm{g})$ & $\begin{array}{c}9.03 \\
(7.09-11.10)\end{array}$ & 9027.53 & $\begin{array}{c}24.30 \\
(19.08-29.89)\end{array}$ & 7290.09 & $\begin{array}{c}60.79 \\
(47.72-74.76)\end{array}$ & 9118.48 \\
\hline $\operatorname{Mn}(\mathrm{g})$ & $\begin{array}{c}1.02 \\
(0.90-1.13)\end{array}$ & 1018.72 & $\begin{array}{c}1.82 \\
(1.60-2.02)\end{array}$ & 544.54 & $\begin{array}{c}3.10 \\
(2.74-3.45)\end{array}$ & 464.83 \\
\hline $\mathrm{Cu}(\mathrm{g})$ & $\begin{array}{c}0.27 \\
(0.20-0.36)\end{array}$ & 274.50 & $\begin{array}{c}0.65 \\
(0.47-0.85)\end{array}$ & 195.87 & $\begin{array}{c}1.46 \\
(1.04-1.89)\end{array}$ & 218.46 \\
\hline $\mathrm{Zn}(\mathrm{g})$ & $\begin{array}{c}1.39 \\
(0.73-2.09)\end{array}$ & 1391.18 & $\begin{array}{c}3.01 \\
(1.57-4.52)\end{array}$ & 901.53 & $\begin{array}{c}6.13 \\
(3.2-9.21)\end{array}$ & 919.77 \\
\hline $\mathrm{B}(\mathrm{g})$ & $\begin{array}{c}0.73 \\
(0.65-0.82)\end{array}$ & 730.84 & $\begin{array}{c}2.32 \\
(2.05-2.60)\end{array}$ & 696.08 & $\begin{array}{c}6.76 \\
(5.98-7.58) \\
\end{array}$ & 1014.42 \\
\hline
\end{tabular}

Tab. 6 - Nutrient export by timber extraction in 1 to 19 years old teak (Tectona grandis L.f.) plantations in Costa Rica and Panama, and comparison between nutrient export and total accumulation (Tab. 5) at 19 yrs old plantations. Nutrient export is estimated from the statistical models summarized in Tab. 4 and represents the sum of the nutrients accumulated in bole and bark. Individual tree estimations (Tab. 4) are used to calculate the stand values, assuming the following densities: 1000,300 and 150 trees ha ${ }^{-1}$ at $1-5,10$ and 19 years, respectively. $(*)$ : Nutrient accumulation estimates obtained by the models at the different ages (confidence intervals are in parentheses, $\alpha=0.05$ ). $(* *)$ : Total accumulation represents the sum of the nutrients accumulated in bole, bark, branches and foliage of a mature stand (19 yrs) near to harvesting (Tab. 5). (***): No statistically sound model could be fitted between bole and bark P and Zn accumulation and age (Tab. 4); therefore estimated bole and bark $\mathrm{P}$ and $\mathrm{Zn}$ accumulation were based on the average from the sampled trees; all collected data was taken into account, no difference could be made based on tree age.

\begin{tabular}{|c|c|c|c|c|c|c|}
\hline \multirow{3}{*}{ Nutrient } & \multicolumn{4}{|c|}{ Nutrient export (bole and bark) } & \multirow{3}{*}{$\begin{array}{l}\text { Total accumulation at } 19 \\
\text { yrs old plantations } \\
\left.(\text { nutrient ha })^{-1}\right)^{* *}\end{array}$} & \multirow{3}{*}{$\begin{array}{c}\text { Nutrient export } \\
\text { compared to total } \\
\text { accumulation at } 19 \text { yrs } \\
\text { old plantations }(\%)\end{array}$} \\
\hline & \multirow{2}{*}{$\frac{5 \mathrm{yr}}{\text { nutrient tree }^{-1}{ }^{*}}$} & \multirow{2}{*}{$\frac{10 \mathrm{yr}}{\text { nutrient tree }^{-1}{ }^{*}}$} & \multicolumn{2}{|c|}{$19 \mathrm{yr}$} & & \\
\hline & & & nutrient tree ${ }^{-1 \text { * }}$ & nutrient $\mathbf{h a}^{-1}$ & & \\
\hline $\mathrm{N}(\mathrm{kg})$ & $\begin{array}{c}0.22 \\
(0.19-0.24)\end{array}$ & $\begin{array}{c}0.59 \\
(0.52-0.65)\end{array}$ & $\begin{array}{c}1.47 \\
(1.31-1.63)\end{array}$ & 219.93 & 404.99 & 54 \\
\hline $\mathrm{Ca}(\mathrm{kg})$ & $\begin{array}{c}0.20 \\
(0.19-0.22)\end{array}$ & $\begin{array}{c}0.64 \\
(0.59-0.69)\end{array}$ & $\begin{array}{c}1.87 \\
(1.73-2.02)\end{array}$ & 280.98 & 660.59 & 43 \\
\hline $\mathrm{K}(\mathrm{kg})$ & $\begin{array}{c}0.21 \\
(0.15-0.27)\end{array}$ & $\begin{array}{c}0.36 \\
(0.25-0.46)\end{array}$ & $\begin{array}{c}0.59 \\
(0.41-0.76)\end{array}$ & 88.48 & 181.85 & 49 \\
\hline $\mathrm{Mg}(\mathrm{kg})$ & $\begin{array}{c}0.06 \\
(0.05-0.07)\end{array}$ & $\begin{array}{c}0.17 \\
(0.14-0.20)\end{array}$ & $\begin{array}{c}0.42 \\
(0.36-0.49)\end{array}$ & 63.39 & 110.52 & 57 \\
\hline $\mathrm{P} * * *(\mathrm{~kg})$ & 0.15 & 0.15 & 0.15 & 23.02 & 32.70 & 70 \\
\hline $\mathrm{S}(\mathrm{kg})$ & $\begin{array}{c}0.03 \\
(0.02-0.04)\end{array}$ & $\begin{array}{c}0.09 \\
(0.05-0.14)\end{array}$ & $\begin{array}{c}0.26 \\
(0.14-0.41)\end{array}$ & 38.85 & 52.98 & 73 \\
\hline $\mathrm{Fe}(\mathrm{g})$ & $\begin{array}{c}4.61 \\
(3.01-6.46)\end{array}$ & $\begin{array}{c}14.62 \\
(9.55-20.52)\end{array}$ & $\begin{array}{c}42.61 \\
(27.84-59.8)\end{array}$ & 6391.91 & 9118.48 & 70 \\
\hline $\operatorname{Mn}(\mathrm{g})$ & $\begin{array}{c}0.26 \\
(0.25-0.27)\end{array}$ & $\begin{array}{c}0.48 \\
(0.46-0.50)\end{array}$ & $\begin{array}{c}0.86 \\
(0.83-0.89)\end{array}$ & 129.3 & 464.83 & 28 \\
\hline $\mathrm{Cu}(\mathrm{g})$ & $\begin{array}{c}0.08 \\
(0.05-0.11)\end{array}$ & $\begin{array}{c}0.24 \\
(0.16-0.34)\end{array}$ & $\begin{array}{c}0.71 \\
(0.46-1.01)\end{array}$ & 107.1 & 218.46 & 49 \\
\hline $\mathrm{Zn} * * *(\mathrm{~g})$ & 1.41 & 1.41 & 1.41 & 211.9 & 919.77 & 23 \\
\hline $\mathrm{B}(\mathrm{g})$ & $\begin{array}{c}0.29 \\
(0.23-0.35)\end{array}$ & $\begin{array}{c}0.92 \\
(0.73-1.12)\end{array}$ & $\begin{array}{c}2.67 \\
(2.13-3.27)\end{array}$ & 400.67 & 1014.42 & 39 \\
\hline
\end{tabular}


Fig. 3 - Tree foliage nutrient accumulation $\left(\mathrm{kg}\right.$ tree $^{-1}$ or $\mathrm{g}$ tree $\left.^{-1}\right)$ as a function of tree age (years) in teak plantations (Tectona grandis L.f.). Points represent the sampled trees at three different locations: Guanacaste, Costa Rica (black circles); Northern Region, Costa Rica (white circles); Panama (black triangles). Lines represent the fitted models reported in Tab. 4.
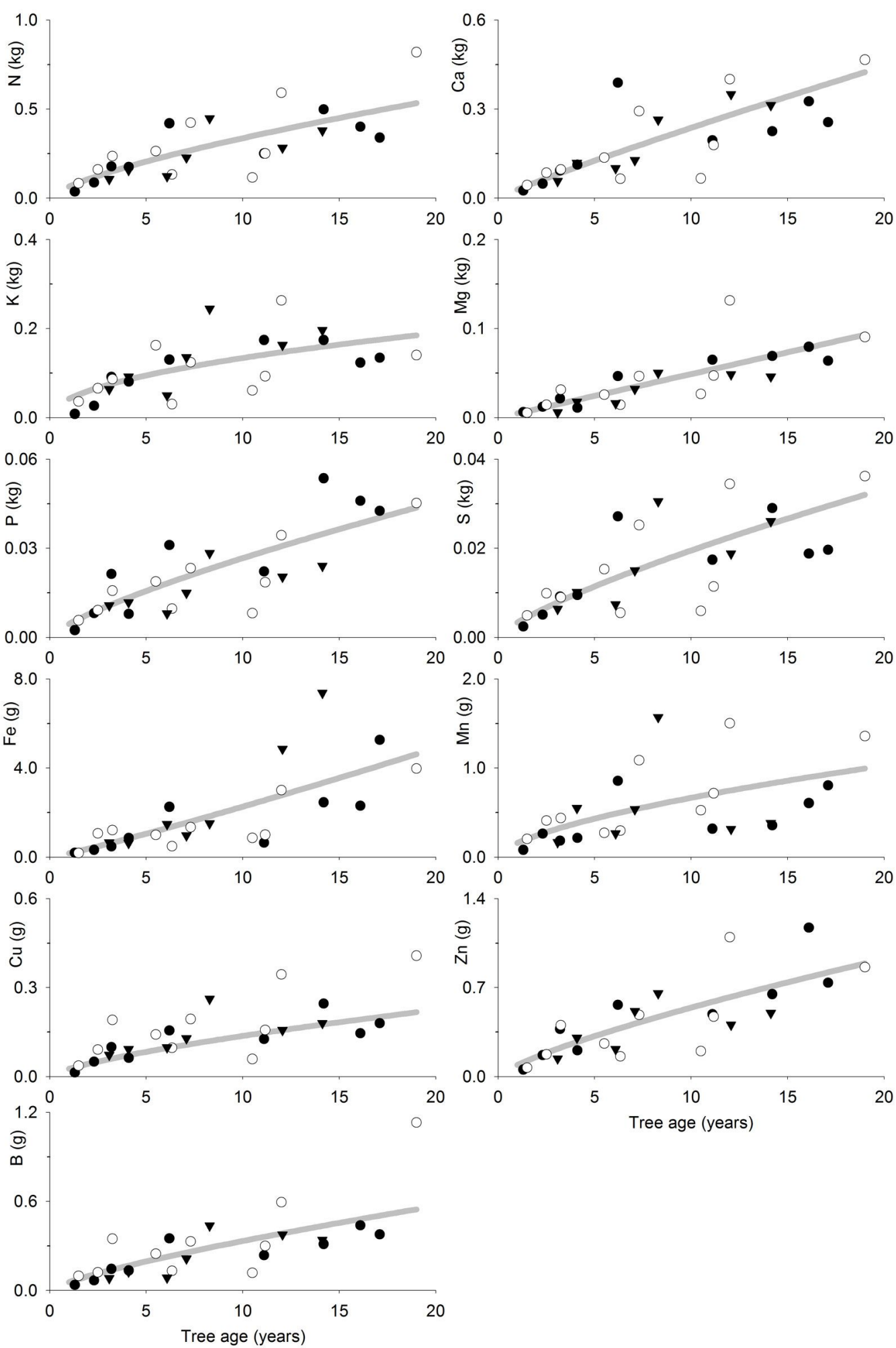

20

$60 \%$ of the total tree biomass at age 5,10 and 19 (Tab. 3, Fig. 2). Branches also accounted for large amounts of biomass compared to total tree biomass but it increased with tree age: $19 \%, 24 \%$ and $30 \%$ at 5,10 and 19 years, respectively (Tab. 3, Fig. 2). However, foliage and bark percentage of total tree biomass decreased with age though the net biomass increased (Tab. 3, Fig. 2): (i) bark biomass was 8,19 and $42 \mathrm{~kg}^{-1} \mathrm{tre}^{-1}$ accounting for $9 \%, 7 \%$ and $5 \%$ of the total tree biomass at 5,10 and 19 years, respectively; (ii) foliage biomass was 10,17 and $29 \mathrm{~kg}$ tree $^{-1}$ accounting for $11 \%, 6 \%$ and $4 \%$ of the total tree biomass at 5, 10 and 19 years, respectively.
Nutrient accumulation and allocation

The fitted models (Tab. 4, Fig. 3 and Fig. 4) allow to estimate the nutrient accumulation at different tree tissues of teak trees based on their age. $\mathrm{N}$ mainly accumulated in foliage during the first years, although bole was the most important sink after 6-7 years. Indeed, bole $\mathrm{N}$ accumulation increased 

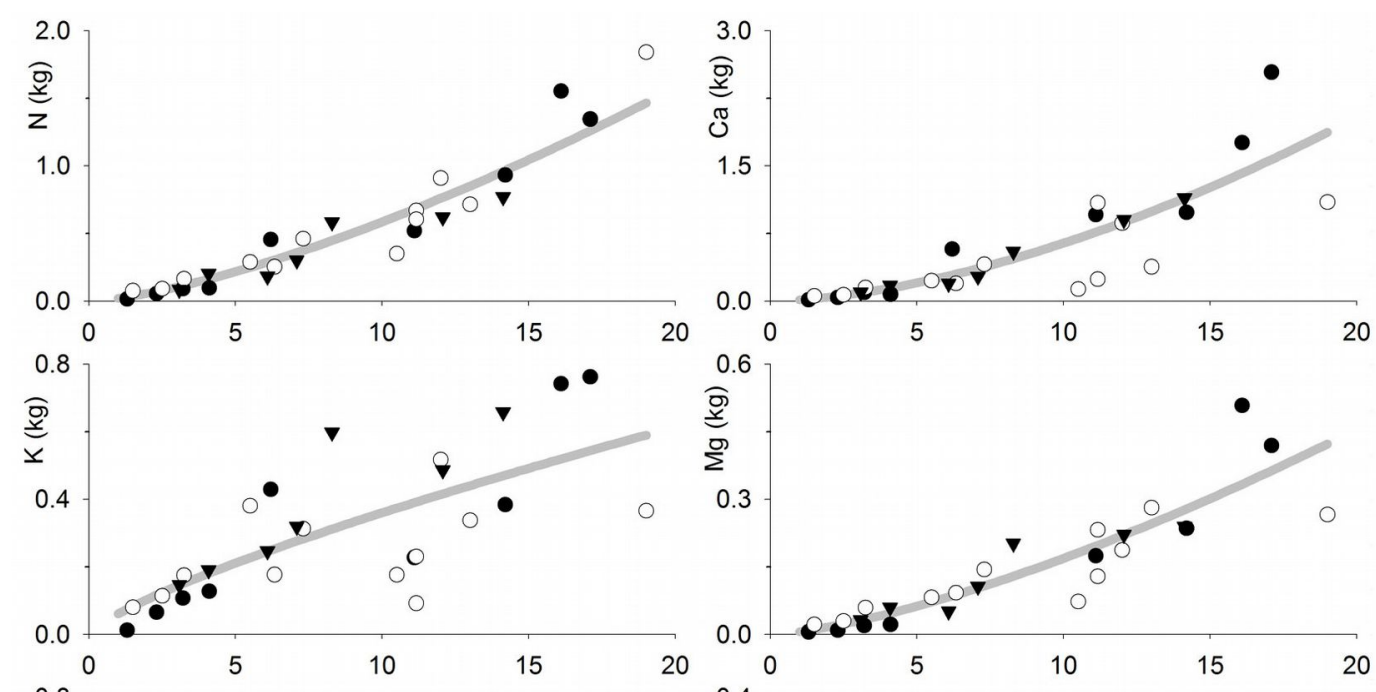

Fig. 4 - Tree bole and bark nutrient accumulation $(\mathrm{kg}$ tree $^{-1}$ or $g$ tree $\left.{ }^{-1}\right)$ as a function of tree age (years) in teak plantations (Tectona grandis L.f.). Points represent the sampled trees at three different locations: Guanacaste, Costa Rica (black circles); Northern Region, Costa Rica (white circles); Panama (black triangles). Lines represent the fitted models reported in Tab. 4.
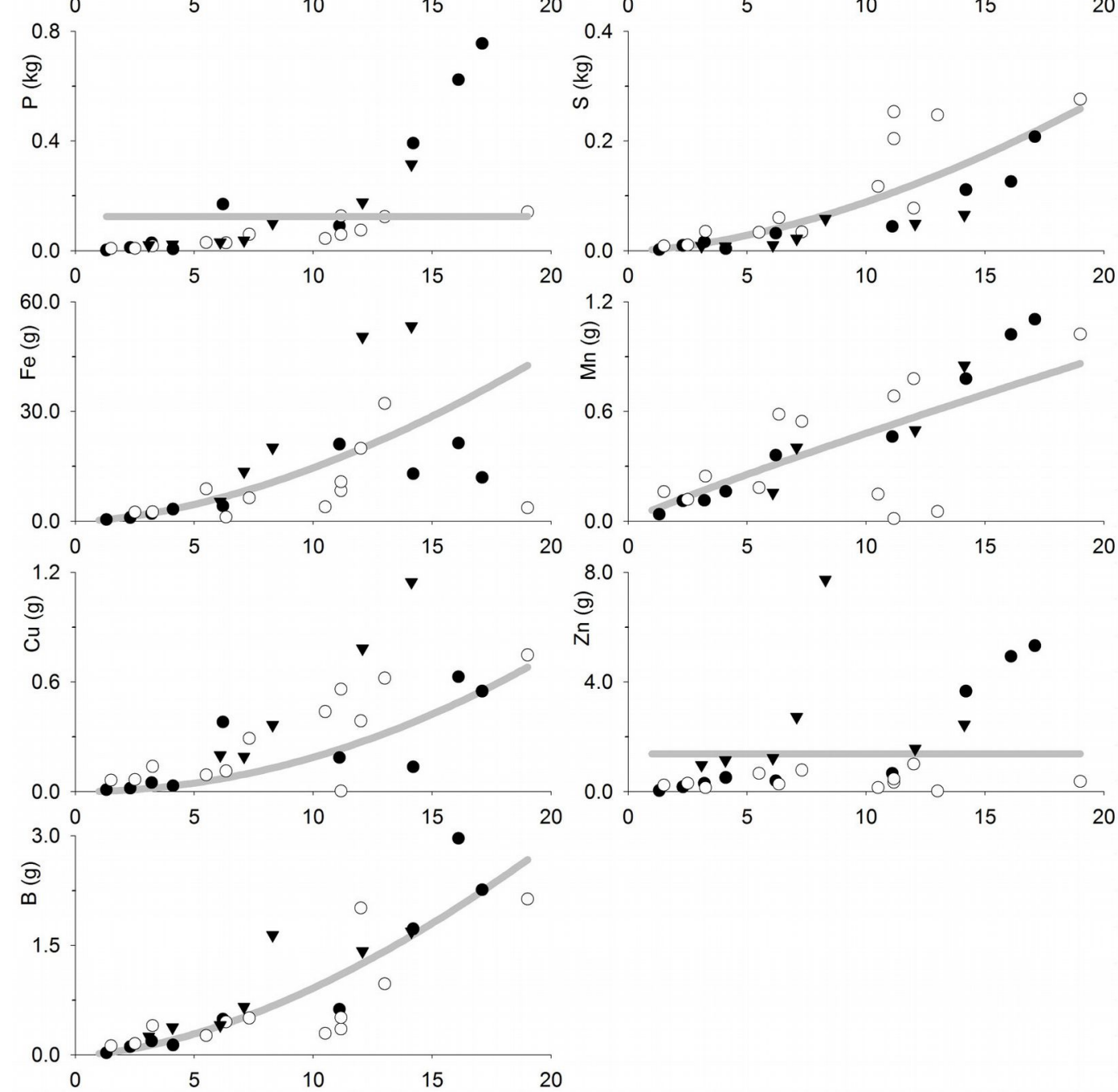

sharply with age, while foliage $\mathrm{N}$ accumulation increased slowly with age. Ca accumulated in branches following a trend close to that of bole and bark. Bark $\mathrm{Ca}$ accumulation was higher than in foliage or bole from 10 years old on, while foliage was higher before that. $\mathrm{K}$ accumulated in branches in trees older than 6-7 years, whereas in younger trees it mainly accumulated at tree bole. Bole $\mathrm{K}$ accumulation was very similar to that of bark and they were both slightly higher than in foliage. $\mathrm{Mg}$ accumulated in tree bole throughout the entire rotation, accumulation in branches was also high; bark and foliage $\mathrm{Mg}$ accumulation were similar and lower than in other tissues. $\mathrm{P}$ and $\mathrm{S}$ also accumu- lated at tree bole and branches while bark and foliage accumulation was low. Fe accumulated at tree bole and branches while foliage accumulation was lowest following a pattern similar to that of bark. Mn also accumulated in tree branches though foliage accumulation was high and even higher than in branches at trees younger than 8-9 years. $\mathrm{Cu}$ 
mainly accumulated in tree bole, while bark accumulation was lowest and foliage accumulation was higher at trees younger than 5 years old. $\mathrm{Zn}$ accumulated in tree bole and branches while bark and foliage accumula tion was low. B mainly accumulated in tree branches, although bark accumulation was high compared to foliage accumulation, which was the lowest.

In the first years, total nutrient accumulation showed a tendency as $\mathrm{P}>\mathrm{K}>\mathrm{N}>\mathrm{Ca}>$ $\mathrm{Mg}=\mathrm{S}>\mathrm{Fe}>\mathrm{Mn}>\mathrm{Zn}>\mathrm{B}>\mathrm{Cu}$; the fifth year it was $\mathrm{N}>\mathrm{Ca}>\mathrm{K}>\mathrm{P}>\mathrm{Mg}>\mathrm{S}>\mathrm{Fe}>$ $\mathrm{Zn}>\mathrm{Mn}>\mathrm{B}>\mathrm{Cu}$; the tenth year it was $\mathrm{Ca}$ $>\mathrm{N}>\mathrm{K}>\mathrm{Mg}>\mathrm{P}>\mathrm{S}>\mathrm{Fe}>\mathrm{Zn}>\mathrm{B}>\mathrm{Mn}$ $>\mathrm{Cu}$; and the nineteenth year it accumulated $\mathrm{Ca}>\mathrm{N}>\mathrm{K}>\mathrm{Mg}>\mathrm{S}>\mathrm{P}>\mathrm{Fe}>\mathrm{B}>\mathrm{Zn}>$ $\mathrm{Mn}>\mathrm{Cu}$. The estimation of the accumulation of some nutrients (mainly P) may not be well represented as it is based on an average of sampled trees from all ages, as no statistical model could be fitted with age as ex planatory variable (Tab. 4). The estimated total tree nutrient accumulation at approximately one rotation period (19 years old) is $2.7 \mathrm{~kg} \mathrm{~N}, 4.4 \mathrm{~kg} \mathrm{Ca}, 1.2 \mathrm{~kg} \mathrm{~K}, 700 \mathrm{~g} \mathrm{Mg}$, $200 \mathrm{~g} \mathrm{P}, 400 \mathrm{~g} \mathrm{~S}, 61 \mathrm{~g} \mathrm{Fe}, 3 \mathrm{~g} \mathrm{Mn}, 1 \mathrm{~g} \mathrm{Cu}, 6$ $\mathrm{g} \mathrm{Zn}$ and $7 \mathrm{~g}$ of $\mathrm{B}$ tree $^{-1}$ (Tab. 5).

\section{Nutrient export}

Timber extraction as thinning or final harvesting implies export of nutrients allocated at bole and bark. Nutrient export varied from thinning to final harvesting as tree bole and bark nutrient allocation varied with age, as well as tree stocking (Tab. 6). Final harvesting constitutes a major nutrient output from the system, considering that 19 year old tree bole and bark nutrient accumulation was: $1.9 \mathrm{~kg} \mathrm{~N}, 1.5 \mathrm{~kg} \mathrm{Ca}, 600 \mathrm{~g} \mathrm{~K}, 300 \mathrm{~g}$ Mg, 400 g P, 200 g S, 43 g Fe, 0.9 g Mn, 0.7 $\mathrm{g} \mathrm{Cu}, 1.4 \mathrm{~g} \mathrm{Zn}$ and $2.7 \mathrm{~g} \mathrm{~B}^{\text {tree }}{ }^{-1}$ (Tab. 6).

\section{Discussion}

\section{Aboveground biomass allocation}

In this study, tree and stand biomass estimates were similar or higher than those reported in other studies (Kaul et al. 1979, Pérez Cordero \& Kanninen 2003, Kumar 2009, Kumar et al. 2009). Such result was expected since only the best performing trees in each sampled stand were selected. However, stand biomass is low when compared to that reported by a spacing trial in southwestern Nigeria (Ola-Adams 1993). Most of the tree biomass was accumulated in the tree bole, accounting for $60 \%$ by itself and $69 \%$ of total tree biomass when considering bole and bark biomass altogether. Similar results were observed by other authors (Kaul et al. 1979, Pérez Cordero \& Kanninen 2003).

Tree biomass increased sharply with tree age (Tab. 3, Fig. 2), whereas stand biomass showed a fast growth during an initial establishment stage (from 6 to $87 \mathrm{Mg} \mathrm{ha}^{-1}$ at years 1 and 5, respectively) and a smaller increment afterwards (from 87 to $121 \mathrm{Mg} \mathrm{ha}^{-1}$ at years 5 and 19, respectively). Little stand biomass variation with tree age or spacing has been shown for teak and other species (Ola-Adams 1993, Pérez Cordero \& Kanninen 2003, Peri et al. 2008). Tree foliage biomass increased with tree age reaching 29 $\mathrm{kg}$ tree $^{-1}$ when trees were 19 years old, whereas its contribution to total tree biomass decreased from $11 \%$ to $6 \%$ and $4 \%$ at 5,10 and 19 years old, respectively, a decreasing trend showed also in other studies (Pérez Cordero \& Kanninen 2003, Kumar 2009). Stand foliage biomass also decreased from 9.7 $\mathrm{Mg} \mathrm{ha}^{-1}$ in the fifth year to $4.4 \mathrm{Mg} \mathrm{ha}^{-1}$ at age 19 , which could be related to declining stand growth capacity ("age-related decline in productivity" - Gower et al. 1996, Ryan et al. 1997, Binkley et al. 2002). This also coincides with the declining trend shown between leaf biomass and tree spacing (OlaAdams 1993), as tree spacing increases with age in the sampled plantations due to the thinning regimen.

\section{Nutrient accumulation and allocation}

$\mathrm{N}$ accumulates mainly at foliage during the first years, because $\mathrm{N}$ foliage concentration is high and foliage is an important component of tree biomass at the beginning of the rotation. However, as foliage becomes a less important tree component and $\mathrm{N}$ foliage concentration decrease (Tab. 2 - Fernández-Moya et al. 2013), the bole becomes the most important $\mathrm{N}$ sink in plantations older than 67 years old, as it is an important biomass sink. A similar pattern is followed by $\mathrm{Ca}$ as it is mostly accumulated in the foliage of young trees (Ola-Adams 1993), where the bark biomass is low, and then is mainly accumulated in the tree bark later (and boleand-bark consequently), which is the general pattern observed for teak and other species (Nwoboshi 1984, Peri et al. 2008, Arias et al. 2011, Qiong et al. 2011). Other elements $(\mathrm{K}, \mathrm{Mg}, \mathrm{P}, \mathrm{S}, \mathrm{Fe}, \mathrm{Cu}, \mathrm{Zn}$ and $\mathrm{B})$ showed a tendency to accumulate mainly at tree bole (or bole and bark) and branches at all ages, probably because the tissue concentration of such elements are lower (Tab. 2 - FernándezMoya et al. 2013), and so is the influence of the nutrient concentration on nutrient accumulation in the biomass. In general, this is consistent with the results of previous studies such as Nwoboshi (1984), who reported that $\mathrm{N}, \mathrm{P}$ and $\mathrm{Mg}$ mainly accumulate in the tree stem, while bark is considered as a $\mathrm{Ca}$ sink. Similarly, other authors reported the bole wood as the main sink for all nutrients considered (Ola-Adams 1993, Kumar et al. 2009).

The relative importance of the different elements in tree nutrient accumulation also varies with tree age. Young teak trees accumulate $\mathrm{P}>\mathrm{K}>\mathrm{N}>\mathrm{Ca}>\mathrm{Mg}=\mathrm{S}>\mathrm{Fe}>\mathrm{Mn}$
$>\mathrm{Zn}>\mathrm{B}>\mathrm{Cu}$, whereas at the end of the rotation they have absorbed $\mathrm{Ca}>\mathrm{N}>\mathrm{K}>\mathrm{Mg}$ $>\mathrm{S}>\mathrm{P}>\mathrm{Fe}>\mathrm{B}>\mathrm{Zn}>\mathrm{Mn}>\mathrm{Cu}$. However, the high $\mathrm{P}$ accumulation at young trees are probably overestimated by the proposed model (Tab. 4) as we could not fit an appropriate model and the average for all ages had to be used. For the same reason, $\mathrm{P}$ accumulation at later ages in the rotation is probably underestimated (Tab. 4, Fig. 3 and Fig. 4). In general, this is consistent with the results of other studies where the nutrients most absorbed by teak were $\mathrm{K}>\mathrm{N}>\mathrm{Ca}>\mathrm{Mg} \geq \mathrm{P}$ (Nwoboshi 1984), $\mathrm{N}=\mathrm{K}>\mathrm{Ca}>\mathrm{Mg}>\mathrm{P}$ (Ola-Adams 1993), $\mathrm{Ca}>\mathrm{K}>\mathrm{N}>\mathrm{Mg}>\mathrm{P}=$ $\mathrm{S}$ (Negi et al. 1995), $\mathrm{Ca}>\mathrm{K}>\mathrm{N}>\mathrm{Mg}>\mathrm{P}>$ $\mathrm{S}$ (Behling 2009) or $\mathrm{N}>\mathrm{Ca}>\mathrm{K}>\mathrm{Mg}>\mathrm{P}>$ $\mathrm{Na}>\mathrm{S}>\mathrm{Cl}$ (Kumar et al. 2009). Hence, the general pattern across different studies is that teak mostly accumulates $\mathrm{Ca}, \mathrm{N}$ and $\mathrm{K}$. However, the most absorbed nutrient varies among the aformentioned investigations, likely depending on soil availability at each particular study site.

The proposed models (Tab. 4) allow managers to calculate the amount and allocation of nutrients accumulated by a well performing tree at different ages. As an example, a stand of 150 trees ha $a^{-1}$ at age 19 would accumulate $405 \mathrm{~kg} \mathrm{~N} \mathrm{ha}^{-1}, 661 \mathrm{~kg} \mathrm{Ca} \mathrm{ha}^{-1}, 182 \mathrm{~kg}$ $\mathrm{K} \mathrm{ha}^{-1}, 111 \mathrm{~kg} \mathrm{Mg} \mathrm{ha}^{-1}, 33 \mathrm{~kg} \mathrm{P} \mathrm{ha}^{-1}, 53 \mathrm{~kg} \mathrm{~S}$ $\mathrm{ha}^{-1}, 9 \mathrm{~kg} \mathrm{Fe} \mathrm{ha}{ }^{-1}, 465 \mathrm{~g} \mathrm{Mn} \mathrm{ha}^{-1}, 218 \mathrm{~g} \mathrm{Cu}$ $\mathrm{ha}^{-1}, 920 \mathrm{~g} \mathrm{Zn} \mathrm{ha}^{-1}, 1 \mathrm{~kg} \mathrm{~B} \mathrm{ha}{ }^{-1}$.

The nutrients accumulated $\left(\mathrm{kg} \mathrm{ha}^{-1}\right)$ in 5 year old teak stands (Tab. 5) represent between $70 \%$ to more than $100 \%$ of nutrients accumulated in 19 year old plantations (Tab. 5). Such evidence provides support to the Miller's theory $(1981,1984,1995)$ that, if nutrition has been appropriate, nutrient uptake decreases when canopy closure occurs and nutrition is mainly based on translocation between tissues of the same tree and nutrient recycling. Alvarado (2012b) estimates than more than $70 \%$ of $\mathrm{N}$ required by a forest plantation could be provided by the mineralization of residues and wet and dry $\mathrm{N}$ deposition. Based on reviewed data, atmospheric $\mathrm{N}$ input could be estimated as high as $230 \mathrm{~kg} \mathrm{ha}^{-1}$ over 20 years of the rotation period for a planted forest (Fölster \& Khanna 1997, Alvarado 2012b), which is approximately $57 \%$ of $\mathrm{N}$ accumulation at the final stages of the rotation period (Tab. 5). However, stand $\mathrm{N}$ accumulation at earlier stages is higher $\left(509 \mathrm{~kg} \mathrm{ha}^{-1}\right.$ at year $5-$ Tab. 5) and atmospheric deposition during 5 years could be estimated as only $57.5 \mathrm{~kg} \mathrm{ha}^{-1}(11 \%$ of the estimated plantation accumulation), pointing out a possible $\mathrm{N}$ deficit at early plantation stages that should be supplied by fertilizers if not supplied by soil N. Atmospheric inputs may vary remarkably from site to site, and a general value from literature cannot be used to close a nutrient balance. However, this points out the probable nutrient deficit in 
teak plantations compared with nutrient accumulation and exports, and hence the need to do more detailed studies to design a nutritional plan including forest fertilization. Fertilization can be considered as another nutrient input to the system but, at this moment, it is usually very low.

The low values of soil available $\mathrm{K}$ and extremely low in the case of $\mathrm{P}$ (Tab. 1) contrast with the relatively high $\mathrm{K}$ and $\mathrm{P}$ accumulation in tree biomass (Tab. 5). This could be explained just by the methodology used to estimate the topsoil availability of $\mathrm{K}$ and especially P. Alternatively, it could be caused by one of the following hypothesis: (a) best performing trees may benefit from a particular site condition with a soil nutrient availability higher than the average, which allows them to have better growth, and/or maybe a deeper root system which allows them to explore a larger soil volume; (b) teak roots may produce phosphatases which improve the mineralization rates of organic-P resulting in levels of available $\mathrm{P}$ higher than those detected by soil analysis (Corryanti et al 2007); (c) those elements could be limiting teak productivity; (d) nutrient input as atmospheric deposition could be playing a key role in plantation nutrition as for these elements.

Well performing teak trees generally accumulate high quantities of $\mathrm{N}, \mathrm{Ca}$ and $\mathrm{K}$. As $\mathrm{Ca}$ soil availability is high if site selection was appropriate, special attention should be paid to other elements such as $\mathrm{N}$, usually considered as limiting the productivity of terrestrial ecosystems; and $\mathrm{K}$, which could become limiting due to its interaction with soil $\mathrm{Ca}$ and the usual high values of the latter. In addition, P and B (Lehto et al. 2010) have also been reported as a limiting factors in forest soils and should be carefully considered. To a lesser extent, other elements such as $\mathrm{Mg}$ showed moderately high requirements, and possible limitations in specific environments may occur due to its interaction with $\mathrm{Ca}$.

\section{Nutrient export}

The proposed models (Tab. 4) allow managers to assess the nutrient export by trees removal (including thinning) at different plantation ages by simply multiplying the number of removed trees by the nutrient removal per tree. Detailed thinning information was not available for the present study; therefore only estimations about nutrient export by final harvesting at the end of the rotation are reported (Tab. 6)

Nutrient export by timber extraction at the end of the rotation represents approximately half of the estimated tree nutrient accumulation of mature stands, varying between $23 \%$ and $73 \%$, depending on the different elements (Tab. 6). The other half of the nutrient absorbed by the tree could remain at the site to be recycled and used in the following rotation, if an appropriate residues management is done (Fölster \& Khanna 1997). Timber extraction by final felling constitutes a major nutrient output from the system, as harvesting (bole and bark) 150 trees $^{\mathrm{h}^{-1}}$ at age 19 would export $220 \mathrm{~kg} \mathrm{~N} \mathrm{ha}^{-1}, 281 \mathrm{~kg}$ $\mathrm{Ca} \mathrm{ha}^{-1}, 88 \mathrm{~kg} \mathrm{~K} \mathrm{ha}^{-1}, 63 \mathrm{~kg} \mathrm{Mg} \mathrm{ha}^{-1}, 23 \mathrm{~kg} \mathrm{P}$ $\mathrm{ha}^{-1}, 39 \mathrm{~kg} \mathrm{~S}^{-1}, 6 \mathrm{~kg} \mathrm{Fe} \mathrm{ha}{ }^{-1}, 129 \mathrm{~g} \mathrm{Mn}$ $\mathrm{ha}^{-1}, 107 \mathrm{~g} \mathrm{Cu} \mathrm{ha}^{-1}, 212 \mathrm{~g} \mathrm{Zn} \mathrm{ha}^{-1}, 401 \mathrm{~g} \mathrm{~B}$ $\mathrm{ha}^{-1}$. Final felling nutrient extraction could be of special relevance in cases such as $\mathrm{P}$ and $\mathrm{K}$, because of their low soil availability (Tab. 1), which could become a limiting factor after several rotations. Estimated $\mathrm{N}$ output at final felling (Tab. 6) is also high; however, no information about soil $\mathrm{N}$ content is available. Reported data for nutrient export is calculated as nutrient accumulated in bole and bark tissues; therefore, it is only a rough estimate, as a percentage of non-commercial stem is left at the site after final felling.

Nutrient export repeated over several rotations could be the cause of soil nutrients depletion (Miller 1984, Fölster \& Khanna 1997, Evans \& Turnbull 2004), determining a decrease in forest productivity after several rotations (Rennie 1955, Evans 2009). The possibility to replace the nutrient output exported with harvesting with fertilization has been traditionally ignored by forest managers (Fölster \& Khanna 1997), although FSC (2004) and several other authors (Rennie 1955, Worrel \& Hampson 1997) recommend the application of fertilizer to sustain shortcycle plantation productivity.

Plantation Stability Indexes have been reported as a good measure to assess soil nutrient mining by forestry plantations (Fölster \& Khanna 1997, Arias et al. 2011). Though such indexes can be considered as good indicators, more research efforts are needed, in particular for their application in the sustainability assessment in certification schemes or for their inclusion in payment for environmental services programs.

To minimize nutrient exports, many authors have proposed to debark tree stems at the plantation site (Rennie 1955, Fölster \& Khanna 1997, Ma et al. 2007). However, such practice may be hardly adopted by forest companies since it is non-profitable and time-consuming. As approximately half of the nutrients translocate from leaves to other tree tissues before senescence (Aerts 1996), bole and bark may have a higher nutrient concentration in the dry season, when teak is defoliated and timber extraction is usually carried out. Therefore, it could be recommended to program the final felling in a time of the year when nutrient exports are minimal. Moreover, if nutrients in the bole and bark had higher concentrations in the dry season compared with the rainy season, this would suppose an underestimation of the nutrient export reported in the present work.
Hence, future research are needed to take such possible influence into account.

\section{Conclusions}

The models proposed in this work allow managers to calculate the amount of nutrients accumulated in bole and bark tree biomass depending on tree age, and can be used to estimate the nutrient extraction under different thinning management scenarios. This is the first study on this subject for Central America and the first step towards a complete nutrient balance for teak plantation systems aimed at a sustainable management of forest plantation.

Teak nutrition should pay special attention to $\mathrm{N}$ and $\mathrm{K}$, together with $\mathrm{Ca}$ the 3 most absorbed nutrients by teak. In addition, $\mathrm{P}$ and $\mathrm{B}$ could also be limiting the productivity in planted teak forest. Nutrient export by timber extraction is high as compared to soil reservoirs, especially for $\mathrm{P}$ and $\mathrm{K}$. The proposed models can serve as a guide for managers to calculate for each specific plantation the minimum nutrient inputs to be added over the rotation period to avoid soil nutrient depletion.

\section{Acknowledgments}

The authors would like to acknowledge the collaboration of Ecoforest (Panama), S.A. and Inversiones Agroforestales Ltd. Panamerican Woods Ltd Expomaderas Ltd. with sampling and for covering the cost of soil and tissue analysis. The authors also thank the personnel of the Natural Resources Laboratory at CIA/UCR for their help in sampling soils and tissues in the field, Richard Anderson (Green Millenium S.A.) and Adam Collins for their comments on the manuscript and for the improvement of English language. RMurillo, EP, JLF, VR, FK and JMV carried out the field measurements and revised the manuscript; RMata and AA conceived the study and revised the manuscript; JFM performed the statistical analysis and wrote the manuscript. The authors also thank two anonymous reviewers for their useful comments to an earlier version of this manuscript.

\section{References}

Aerts R (1996). Nutrient resorption from senescing leaves of perennials: are there general patterns? Journal of Ecology 84: 597-608. - doi: $10.2307 / 2261481$

Alvarado A (2012a). Diagnóstico de la nutrición en plantaciones forestales [Diagnosis of nutrient status in forest plantations]. In: "Nutrición y fertilización forestal en regiones tropicales" (Alvarado A, Raigosa J eds). Asociación Costarricense de las Ciencias del Suelo, San José, Costa Rica, pp. 93-120. [in Spanish]

Alvarado A (2012b). Nutrición y fertilización de Tectona grandis Linn. f. [Nutrient management and fertilization of Tectona grandis Linn. f.]. In: 
"Nutrición y fertilización forestal en regiones tropicales" (Alvarado A, Raigosa J eds). Asociación Costarricense de las Ciencias del Suelo, San José, Costa Rica, pp. 313-340. [in Spanish]

Arias D, Calvo-Alvarado J, de Ritchter D., Dohrenbusch A (2011). Productivity, aboveground biomass, nutriet uptake and carbon content in fast-growing tree plantations of native and introduced species in Southern Region of Costa Rica. Biomass and Bioenergy 35: 1779-1788. doi: 10.1016/j.biombioe.2011.01.009

Behling M (2009). Nutrição, partição de biomassa e crescimento de povoamentos de Teca em Tangará da Serra-MT [Nutrition, biomass allocation and growth of teak plantations in Tangará da Serra-MT]. Ph. D. Thesis, Universidade Federal de Viçosa, MG, Brazil, pp. 156. [in Spanish]

Bertsch F (1998). La fertilidad de los suelos y su manejo [Management of soil fertility]. Asociación Costarricense de la Ciencia del Suelo, San José, Costa Rica, pp. 157. [in Spanish]

Binkley D, Stape JL, Ryan MG, Barnard HR, Fownes J (2002). Age-related decline in forest ecosystem growth: an individual-tree, standstructure hypothesis. Ecosystems 5: 58-67. - doi: 10.1007/s10021-001-0055-7

Corryanti J, Soedarsono J, Radjagukguk B, Widyastuti SM (2007). Phosphatase activity in the rhizosphere and root of mycorrhizal teak seedlings with three levels of NPK fertilization. Biodiversitas 8 (2): 204-209. [in Indonesian with English abstract] [online] URL: http://biodiversitas.mipa.uns.ac.id/D/D0803/D080308.pdf

De Camino R, Alfaro MM, Sage LFM (2002) Teak (Tectona grandis) in Central America. FAO Plantations Working Papers FP/19, Rome, Italy, pp. 78.

Evans J (2009). Planted forests: uses, impacts and sustainability. CAB International, FAO, Rome, Italy, pp. 213.

Evans J, Turnbull JW (2004). Plantation forestry in the Tropics. Oxford University Press, New York, NY, USA, pp. 482.

Fernández-Moya J, Murillo R, Portuguez E, Fallas JL, Ríos V, Kottman F, Verjans JM, Mata R, Alvarado A (2013). Nutrient concentrations age dynamics of teak plantations (Tectona grandis L.f.) in Central America. Forest Systems 22 (1): 123133. - doi: $10.5424 /$ fs/2013221-03386

Forsythe W (1975). Física de Suelos. Manual de Laboratorio [Soil physics. A laboratory manual]. IICA, Turrialba, Costa Rica, pp. 215. [in Spanish]

Fölster H, Khanna PK (1997). Dynamics of nutrient supply in plantation soils. In: "Management of Soil, Nutrients and Water in Tropical Plantation Forests" (Nambiar EKS, Brown AG eds). Australian Centre for International Agricultural Research, Bruce, ACT, Australia, pp. 339-379.

FSC (2004). Perspectivas sobre plantaciones: Desafío para el manejo de plantaciones [Perspectives on plantations: a review of the issues facing plantation management]. Forest Stewardship Council AC, Bonn, Germany, pp. 28. [in Spanish]

Gower ST, Mcmurtrie RE, Murty D (1996).
Aboveground net primary production decline with stand age: potential causes. Trends in Ecology and Evolution 11 (9): 378-382. - doi: 10.10 16/0169-5347(96)10042-2

Holdridge LR (1947). Determination of world plant formations from simple climatic data. Science 105: 367-368. - doi: 10.1126/science.105. 2727.367

Horneck DA, Miller RO (1998). Determination of total nitrogen in plant tissue. In: "Handbook of reference methods for plant analysis" (Kalra YP ed). Soil and Plant Analysis Council Inc. and CRC Press, Boca Raton, FL, USA, pp. 75-83.

Johnson EA, Miyanishi K (2008). Testing the assumptions of chronosequences in succession. Ecology Letters 11 (5): 419-431. - doi: 10.1111/ j.1461-0248.2008.01173.x

Kaul ON, Sharma DC, Tandon VN, Srivastava PPL (1979). Organic matter and plant nutrients in a teak (Tectona grandis) plantation. Indian Forester 105 (8): 573-582.

Kollert W, Cherubini L (2012). Teak resources and market assessment 2010. FAO Planted Forests and Trees Working Paper FP/47/E, Rome, Italy, pp. 42.

Kumar PS (2009). Nutrient dynamics of Teak platations and their impact on soil productivity a case study from India. In: "XIII World Forestry Congress". Buenos Aires (Argentina) 18-23 Oct 2009, oral presentation.

Kumar JIN, Kumar RN, Kumar BR, Sajish PR (2009). Quantification of nutrient content in the aboveground biomass of teak plantation in a tropical dry deciduous forest of Udaipur, India. Journal of Forests Science 55 (6): 251-256.

Laclau JP, Deleporte P, Ranger J, Bouillet JP, Kazotti G (2003). Nutrient dynamics troughout the rotation of Eucalyptus clonal stands in Congo. Annals of Botany 91: 879-892. - doi: 10.1093/aob/ $\mathrm{mcg} 093$

Lehto T, Ruuhola T, Dell B (2010). Boron in forest trees and forest ecosystems. Forest Ecology Management 260: 2053-2069. - doi: 10.1016/ j.foreco.2010.09.028

Ma X, Heal KV, Liu A, Jarvis PG (2007). Nutrient cycling and distribution in different-aged plantations of Chinese fir in southern China. Forest Ecology Management 243: 61-74. - doi: 10.1016/j.foreco.2007.02.018

Miller HG (1981). Forest fertilization: some guiding concepts. Forestry 54 (2): 157-167. - doi: 10.1093/forestry/54.2.157

Miller HG (1984). Dynamics of nutrient cycling in plantation ecosystems. In: "Nutrition of Plantation Forests" (Bowen GD, Nambiar EKS eds). Academic Press, London, UK, pp. 53-79.

Miller HG (1995). The influence of stand development on nutrient demand, growth and allocation. Plant and Soil 168-169 (1): 225-232. - doi: 10.10 07/BF00029332

Nambiar EKS (1995). Sustained productivity of plantations: science and practice. Bosque 16 (1): 3-8.

Negi MS, Tandon VN, Rawat HS (1995). Biomass and nutrient distribution in young teak (Tectona grandis Linn. f.) plantation in Tarai
Region of Uttar Pradesh. Indian Forestry 121 (6): 455-464.

Nwoboshi LC (1984). Growth and nutrient requirements in a teak plantation age series in Nigeria. II. Nutrient accumulation and minimum annual requirements. Forest Science 30 (1): 3540. [online] URL: http://www.ingentaconnect. com/content/saf/fs/1984/00000030/00000001/art 00008

Ola-Adams BA (1993). Effects of spacing on biomass distribution and nutrient content of Tectona grandis Linn. f. (teak) and Terminalia superba Engl. and Diels. (afara) in south-western Nigeria. Forest Ecology Management 58: 299319. - doi: 10.1016/0378-1127(93)90152-D

Pandey D, Brown C (2000). Teak: a global overview. Unasylva 51 (2): 1-15. [online] URL: http://tropenwald.ch/files/projects/PD_24_98_article_1.pdf

Pérez Cordero LD, Kanninen M (2003). Aboveground biomass of Tectona grandis plantations in Costa Rica. Journal of Tropical Forest Sciences 15 (1): 199-213. [online] URL: http://www ambientetierra.com/pdf docs/AbovegroundBiomassOnTeak_Perez-Kanninen.pdf

Peri PL, Gargaglione V, Martínez-Pastur G (2008). Above- and belowground nutrients storage and biomass accumulation in marginal Nothofagus antarctica forests in southern Patagonia. Forest Ecology Management 255: 25022511. - doi: 10.1016/j.foreco.2008.01.014

Poels RLH (1994). Nutrient balance studies to determine the sustainability of management systems of natural and plantation forests in Costa Rica. CATIE/AUW/MAG, San José, Costa Rica, pp. 36.

Qiong Z, Xing-yu L, De-hui Z (2011). Aboveground biomass and nutrient allocation in an age-sequence of Larix olgensis plantations. Journal of Forest Resources 22 (1): 71-76. - doi: 10.1007/s11676-011-0128-1

Ranger J, Marques R, Colin-Belgrand M, Flammang N, Gelhaye D (1995). The dynamics of biomass and nutrient accumulation in a Douglasfir (Pseudotsuga menziesii Franco) stand studied using a chronosequence approach. Forest Ecology Management 72: 167-183. - doi: 10.1016/03 78-1127(94)03469-D

Rennie PJ (1955). The uptake of nutrients by mature forest growth. Plant and Soil 8 (1): 49-95. doi: 10.1007/BF01343546

Ryan MG, Binkley D, Fownes JH (1997). Age-related decline in forest productivity: pattern and process. Advances in Ecological Research 27: 213-262. - doi: 10.1016/S0065-2504(08)60009. 4

Sadler EJ, Karlen DL (1995). Aerial dry matter and nutrient accumulation comparisons among five soybean experiments. Communications on Soil Science and Plant Analysis 26: 3145-3163. doi: 10.1080/00103629509369516

SAS Institute Inc (2002). SAS/STAT®9.0 User's Guide. SAS Institute Inc., Cary, NC, USA.

Siddiqui MT, Abod SA, Tariq MA (2007). Root nutrient concentrations in teak (Tectona grandis L.f.) plantations as influenced by fertilization 
and age. Canadian Journal of Pure and Applied Sciences 1 (1): 45-52. [online] URL: http://cjpas.net/Jul-07.pdf\#page $=46$

Srivastava SK, Singh KP, Upadhyay RS (1986).
Fine root growth dynamics in teak (Tectona grandis Linn F.). Canadian Journal of Forest Research 16: 1360-1364. - doi: 10.1139/x86-240

Worrel R, Hampson A (1997). The influence of some forest operations on the sustainable management of forest soils - a review. Forestry 70 (1): 61-85. - doi: 10.1093/forestry/70.1.61 